\title{
The Benthic Megafaunal Assemblages of the CCZ (Eastern Pacific) and an Approach to their Management in the Face of Threatened Anthropogenic Impacts
}

\section{OPEN ACCESS}

Edited by:

Ricardo Serrão Santos,

University of the Azores, Portugal

Reviewed by:

Akkur Vasudevan Raman,

Marine Biological Laboratory, Andhra

University, India

Autun Purser,

Alfred Wegener Institut Helmholtz

Zentrum für Polar und

Meeresforschung (AWI), Germany

${ }^{*}$ Correspondence: Virginie Tilo virginie.tilot@mnhn.fr; v.tilot@wanadoo.fr

Specialty section: This article was submitted to Deep-Sea Environments and Ecology,

a section of the journal

Frontiers in Marine Science

Received: 18 October 2017

Accepted: 10 January 2018

Published: 20 February 2018

Citation:

Tilot $V$, Ormond $R$, Moreno Navas $J$ and Catalá TS (2018) The Benthic Megafaunal Assemblages of the CCZ (Eastern Pacific) and an Approach to

their Management in the Face of Threatened Anthropogenic Impacts.

Front. Mar. Sci. 5:7.

doi: 10.3389/fmars.2018.00007

\begin{abstract}
Virginie Tilot ${ }^{1,2 *}$, Rupert Ormond ${ }^{3,4}$, Juan Moreno Navas ${ }^{5}$ and Teresa S. Catalá ${ }^{6,7,8}$
${ }^{1}$ UMS (AFB CNRS MNHN) Patrimoine Naturel, Muséum National d'Histoire Naturelle, Paris, France, ${ }^{2}$ Instituto Español de Oceanografía, Malaga, Spain, ${ }^{3}$ Centre for Marine Biodiversity and Biotechnology, Heriot-Watt University, Edinburgh, United Kingdom, ${ }^{4}$ Marine Conservation International, Edinburgh, United Kingdom, ${ }^{5}$ Physical Oceanography Research Group, Universidad de Málaga, Málaga, Spain, ${ }^{6}$ ICBM-MPI Bridging Group for Marine Geochemistry, Institute for Chemistry and Biology of the Marine Environment (ICBM), University of Oldenburg, Oldenburg, Germany, ${ }^{7}$ Departamento de Ecología and Instituto del Agua, Universidad de Granada, Granada, Spain, ${ }^{8}$ Consejo Superior de Investigaciones Científicas - Instituto de Investigacións Mariñas (CSIC-IIM), Vigo, Spain
\end{abstract}

We present here the results of a UNESCO/IOC baseline study of the megafaunal assemblages of the polymetallic nodule ecosystem of 5 areas within the Clarion Clipperton Zone (CCZ) of the eastern Pacific Ocean. The work was undertaken with a view to investigating the structure of the epifaunal populations associated with the benthic biotopes being targeted for nodule mining and developing an appropriate set of management tools and options. The general characteristics of nodule ecosystem and assemblages and their sensitivity to deep-sea mining are discussed in relation to water masses, surface to seabed water circulation, the nepheloid layer and processes taking place at the sediment interface. Management tools considered include species diversity and vulnerability indexes, GIS systems, zoning, and 3D rapid environmental assessment (REA). These strategies are proposed for trial during pilot mining operations within the CCZ.

Keywords: deep sea mining, polymetallic nodule ecosystem, epibenthic megafauna, vulnerable marine ecosystems, ecosystem-based marine spatial planning

\section{INTRODUCTION}

Knowledge of the structure of its megafaunal assemblages is essential to understanding the functioning of any deep-sea ecosystem (Rex and Etter, 2010). Typically this faunal component includes a significant fraction (17-50\%) of benthic abyssal biomass (Haedrich and Rowe, 1977). Since the megafauna is also one of the principal agents of bioturbation at the depositional interface of the deep-sea benthos (Mauviel and Sibuet, 1985; Levin et al., 1986), it can influence many other biological and geochemical components of the deep ocean, in particular concerning the nodule ecosystem (Sharma and Rao, 1992) (Figure 1). In particular, the benthic fauna plays an important role in carbon cycling and mineralization within the epibenthos. Interestingly it also contributes to the genesis of polymetallic nodules, bioturbation along with bottom currents playing a role in allowing nodules to remain on the seafloor (Dugolinsky et al., 1977; Du Castel, 1985; Mullineaux, 1987; Thiel et al., 1993; Veillette et al., 2007a,b). 
Megafaunal assemblages also serve as a good indicator of the status of a habitat in the face of natural and anthropogenic impacts (Bluhm et al., 1995), and may be used to measure the variation in flux of particulate organic carbon (Smith et al., 1997), to identify critical environmental parameters, to characterize selected habitats and associated nodule facies (Tilot, 2006a), and to measure rates of recolonization under natural or impacted conditions (Tilot, 1988, 1989, 1990, 1991; Bluhm, 1997, 2001).

The large equatorial polymetallic nodule belt of the Clarion Clipperton Zone (CCZ) $\left(118^{\circ}-157^{\circ} \mathrm{W} / 9^{\circ}-16^{\circ} \mathrm{N}\right)$, wherein lie the most economically important deposits (Morgan, 2000; Petersen et al., 2016) (Figure 2), covers about 2 million $\mathrm{km}^{2}$ of abyssal hills and escarpments in the eastern Pacific (Halbach et al., 1988; Kotlinski, 1998). Considerable regional-scale variation in the geological environment (topography, erosion by deep ocean currents and regional deposition of sediments) has led to a classification of nodule deposits and the recognition of a series of distinct "nodule-facies" (Hoffert and Saget, 2004; Hoffert, 2008), differentiation which has been based on a combination of photographic study and of collection of samples for morphological and geochemical assessment (Table 1).

We had the opportunity to participate in a comprehensive study of the biodiversity and distribution of epibenthic megafauna of the CCZ, originally with IFREMER (L'Institut Français de Recherche pour l'Exploitation de la Mer), France, and funding from the EU and the Institut océanographique, France (Tilot, 1988, 1989, 1991, 1992, 2006c; ESCO CNRS IFREMER, 2014), following which the work was updated and expanded (Tilot, 2006a), with particular emphasis on the echinoderm fauna (Tilot, 2006b), with the support of the Intergovernmental Oceanographic Commission (IOC) of UNESCO (published in 3 vol. see: http://unesdoc.unesco.org/images/0014/001495/ 149556e.pdf\#223), in order to establish a UNESCO/IOC baseline. Because of unavoidable conditions, the findings could not be published at the time, other than is restricted circulation reports.

More recently, however, this research has led to the development of options for the management and conservation of the nodule ecosystem, taking in to account relevant scientific, legal and institutional issues (Tilot, 2010a). Similar options have been proposed for other deep-sea habitats and discussed at a UNESCO meeting of experts (Académie des Sciences d'OutreMer (ASOM), 2010) which provided an international platform for consideration of these issues (Tilot, 2011) and initiated the development of a number of management and conservation tools (Tilot, 2013, 2014). In particular, the application of a strategic approach to marine spatial planning and of the concept of marine sanctuaries to the high seas was considered (Tilot, 2004; Ardron et al., 2008). The present study has taken this approach further to propose the application of multilayer Rapid Ecological Assessment (REA) (Price et al., 1998; Price, 2004), of management indexes (Tilot et al., 2008a,b; Tilot, 2013, 2016) and of ecohydrodynamics (Moreno Navas et al., 2014), to one or more of the UNESCO/IOC baseline sites.

The present support for international scientific collaboration in multidisciplinary research investigating the environmental impacts of extracting energy resources and minerals from the deep sea provides an opportunity to present our findings. In particular, our areas of study are in line with the objectives of the research programme funded under the European Commission's Framework 7 initiative (e.g. Midas) and the present joint action on deep seabed mining impact initiated under the Strategic Research and Innovation Agenda of the JPI Healthy and Productive Seas and Oceans programme funded by EU's Horizon 2020. The results we present here contribute toward the urgently required full description of the referential state of the areas to be mined (Gollner et al., 2017).

\section{METHODS AND STUDY AREA}

The study areas, data from which were used during the UNESCO/IOC baseline study (Tilot, 2006a,b, 2010a), were the NORIA region, within which lie the NIXO 45 and NIXO 41 sites, the American site ECHO 1, and the consortium site IOM BIE (Russia, Bulgaria, Cuba, Poland, Czech Republic, Slovakia) (Figure 2); the most detailed and recent work focussed on NIXO 45, a particularly well explored and sampled site within Ifremer's marine geosciences programmes. The NORIA (AFERNOD) area covers about $450,000 \mathrm{~km}^{2}$ delimited between $125^{\circ} \mathrm{W} / 135^{\circ} \mathrm{W}$ and $11^{\circ} \mathrm{N} / 16^{\circ} \mathrm{N}$, and was surveyed from 1974 on a grid pattern with a station every $2.4 \mathrm{~km}$, in order to determine the structural, bathymetric and sedimentary environment of the nodules. The NIXO 45 site lies within $130^{\circ} 00^{\prime} \mathrm{W} / 130^{\circ} 10^{\prime} \mathrm{W}, 13^{\circ} 56^{\prime} \mathrm{N} / 14^{\circ} 08^{\prime} \mathrm{N}$, at a mean depth of $4,950 \mathrm{~m}$. The NIXO 41 site lies within $127^{\circ} \mathrm{W} / 130^{\circ} \mathrm{W}, 12^{\circ} 10^{\prime} \mathrm{N} / 13^{\circ} 35^{\prime} \mathrm{W}$ at an depth of $4,700-5,000 \mathrm{~m}$, and extends eastwards to NIXO 45. The ECHO I site is located at $14^{\circ} 40^{\prime} \mathrm{N}-125^{\circ} 25^{\prime} \mathrm{W}$ at a depth of $4,500 \mathrm{~m}$. And the IOM BIE site has a midpoint at $11^{\circ} 04^{\prime} \mathrm{N} ; 119^{\circ} 40^{\prime} \mathrm{W}$ and an average depth of $4,300 \mathrm{~m}$.

The methods used for data collection were those standard at the time. The platforms used for video and still photography and physical sampling within the UNESCO/IOC baseline study areas were: the French towed device "Remorquage Abyssal d'Instruments pour l'Exploration" (RAIE), the suprabenthic camera sleigh "Troika," the French camera coupled free sampler "ED1," the autonomous unmanned "Epaulard," the French manned submersible "the Nautile" for the French sites, the American "Deep Tow Instrumentation System" for ECHO I site and for the IOM BIE site, the Russian towed cameras MIR-1 and NEPTUN, and also box cores with photo cameras. Details of these platforms and the photographic and other sampling gear and methods are provided in the UNESCO/IOC report (Tilot, 2006a) (Table 2; Figure 3).

The assessment of the megafaunal communities presented here is based on the analysis of more than 200,000 photos of the seafloor and more than $55 \mathrm{~h}$ of videos. To permit effective interpretation, a photographic atlas was assembled for all the observed megafaunal morphotypes, identified to the highest practicable taxonomic level in collaboration with an international network of taxonomists. The atlas was annotated with observations on the morphology, ethology and feeding behavior of each taxon thus further facilitating identification of the species observed on the imagery. Comparisons were also made with the fauna recorded from the Peruvian basin analyzed during the DISCOL cruise (Tilot, 1989). Information on 


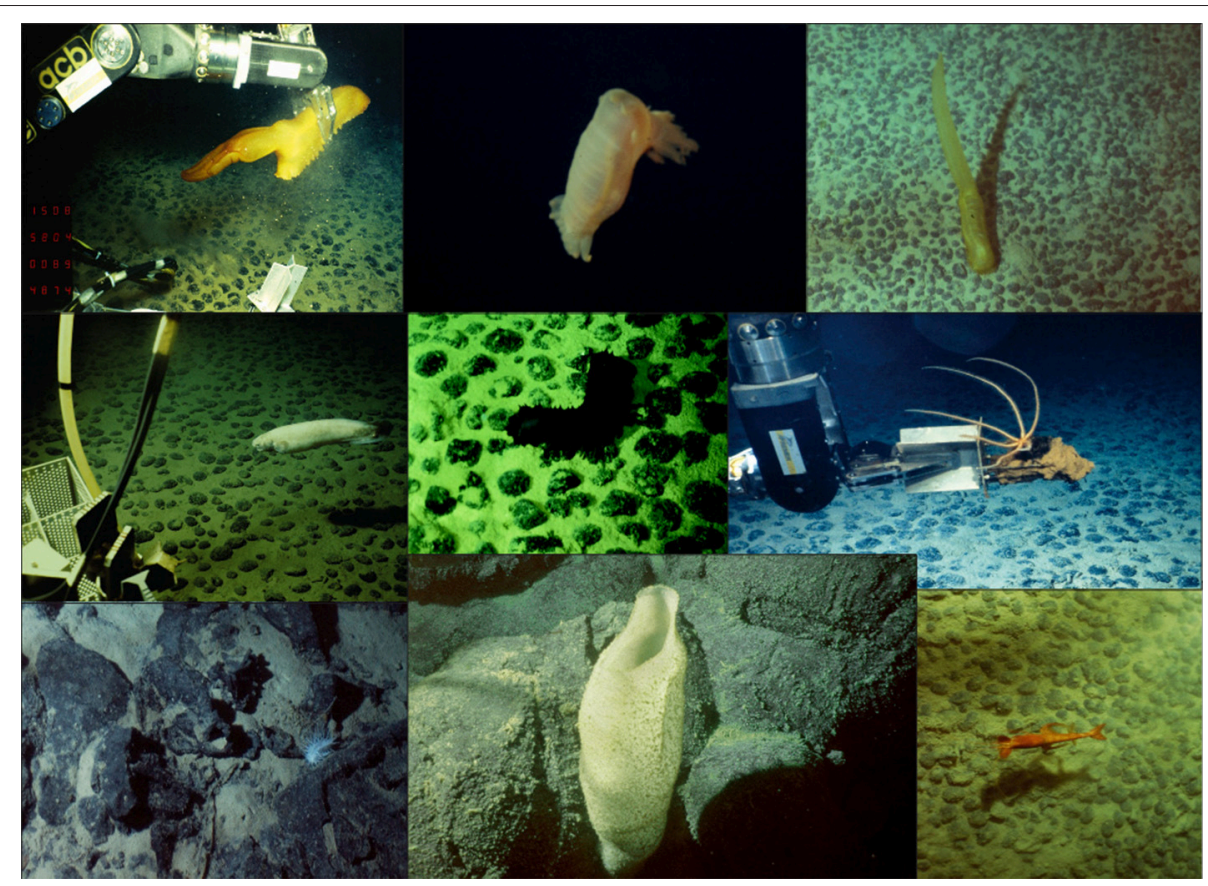

FIGURE 1 | Photos of megafauna in the nodule ecosystem taken by the manned submersible "Nautile." From top left to bottom right starting from top: (1) Holothurian Psychropotes longicauda being collected over facies C 15\% @IFREMER; (2) Swimming Holothurian Peniangone leander ( )IFREMER; (3) Holothurian Psychropotes longicauda on facies C 40\%@IFREMER; (4) Fish Ophidiid Barathrites sp., over facies C15\%@IFREMER; (5) Holothurian Psychronaetes hanseni on facies C20\% (IFREMER; (6) Crustacean Decapoda Plesiopenaeus sp. or Aristaeomorpha sp. CIFREMER; Source: Tilot (2010b).

the geographic and bathymetric distribution of each taxon was compiled from data from abyssal regions, mainly in the Pacific and Atlantic, outside the CCZ. Hypotheses of identification for each taxa were collated on the advice of international specialists listed in Appendix I of UNESCO/IOC baseline volume 1 (Tilot, 2006a) (Supplementary Material Document 1).

Data was analyzed using a programme developed by Ifremer for studying the spatial distribution of megafauna photographed in situ (Sibuet, 1987). This computer program adds in successive increments the surface area of each photograph calculated from the camera altitude. A multivariate analysis of relationships was then performed with a CYBER 992-31 calculator using SPAD N software.

The bottom topography and distribution of the main facies in NIXO 45 were mapped with facies type being superimposed on plots of several seabed terrain variables using QGIS. These variables included depth, slope (degrees of inclination), aspect (the orientation of the seafloor measured in degrees), and rugosity (a non-metric measure of topographic unevenness).

\section{Value and Sensitivity Indices for NIXO 45}

Based on data gathered during the UNESCO/IOC baseline survey of NIXO 45 we developed two provisional indices for management use. The first is a Value Index which incorporates the perceived significances of a range of physico-chemical and biological features described in the Results section. The second is a Sensitivity Index which is based on the likely impacts of exploitation on the observed communities as judged by the available literature. We then assess, based on the available data, the component values for each of the facies recorded in the study and so calculate first the Value Index and then the Sensitivity Index for each facies. The significance and derivation of this approach is explained further in the Discussion section.

\section{RESULTS}

Since space limits the extent to which full data can be included, we present here only the main findings. Examples of the megafauna detected through use of video and still imagery are shown in Figure 2 .

\section{NORIA}

Within the wider NORIA area a total of 159 taxa were recorded representing 13 phyla. These were mainly cnidarians (59 taxa), echinoderms (50 taxa including 32 holothurians), chordates (23 taxa including $17 \mathrm{fish}$ ) and sponges (21 taxa). Suspension feeders (68 sessile and 10 mobile taxa), that were mainly cnidarians and sponges, displayed a higher taxonomic richness than deposit feeders, that were mainly echinoderms (60 taxa, among which 50 taxa are mobile) and carnivores/scavengers (45 taxa).

\section{NIXO 45}

The NIXO 45 site was studied in greater detail that the others. Within it, facies BP and A occurred on slopes and close to escarpments, facies B on the hills rising to about $4,750 \mathrm{~m}$, facies $\mathrm{C}$ on the valleys, facies $\mathrm{O}$ ancient sediments on the whole area 


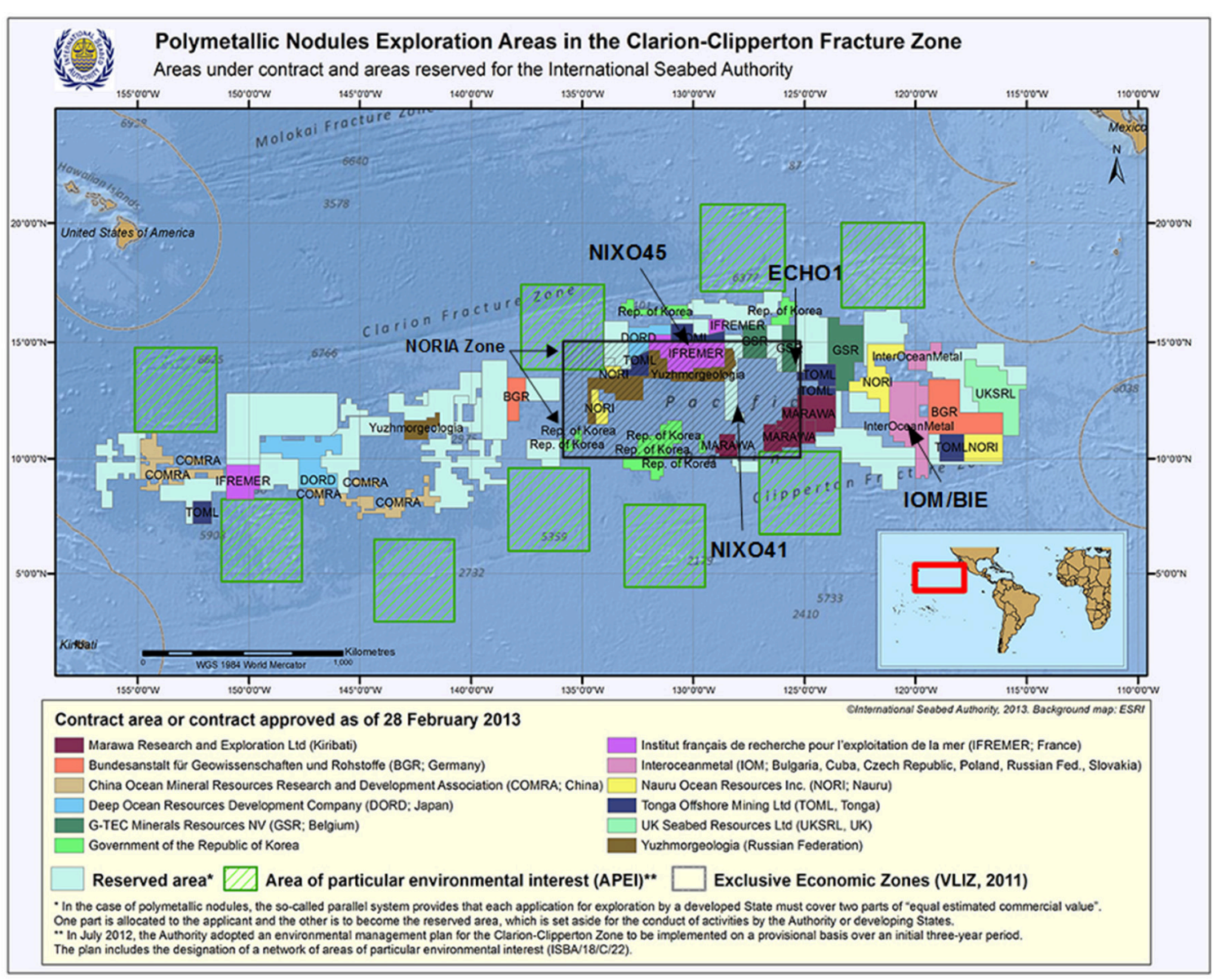

FIGURE 2 | Updated map adapted from https://www.isa.org.jm of the CCZ showing the areas under contract and the areas reserved for the International Seabed Authority, as well as the Areas of Particular Environmental Interest (APEI) and the UNESCO/IOC Baseline Study areas (NORIA, NIXO 45, NIXO 41, Echo 1, IOM BIE).

deeper than 5,000 $\mathrm{m}$ and on the accumulation areas, and facies $\mathrm{O}$ recent sediments in some transition areas on the valleys when facies C is absent (Du Castel, 1985; Tilot, 2006a). Part of NIXO 45 containing minor structures such as plateaux, hills, secondary valleys and a central depression, with a maximum depth of $5,150 \mathrm{~m}$, is illustrated in Figure 4.

Within Nixo 45, 134 different taxa were identified from the analysis of $70,000 \mathrm{~m}^{2}$ of photographed surface; cnidarians outnumbered echinoderms (as in NORIA as a whole) and sponges. Nodule coverage and abiotic factors such as slope, topography and bathymetry appeared to largely determine the abundance and composition of the faunal assemblage. Overall a higher taxonomic richness was recorded on all nodule facies, with 48 taxa recorded on facies C $2-15 \%$. However, 36 taxa were found on Facies $\mathrm{O}$ with recent sediments, more than on facies B and BP (34 taxa), likely because this facies is located on the same valleys as facies $C$ and represents a transition facies between patches of facies $C$ with low nodule coverage. This facies may have nodules under the surface which is not the case with facies $\mathrm{O}$ on ancient sediments located in deeper basins. More specifically the habitats in decreasing order of species richness were: facies C 10, facies $\mathrm{O}$ with recent sediments, facies $\mathrm{C} 15 \%$, facies C20\%, facies BP 35\%, facies C2-5\%, facies B 50\%, facies BP $50 \%$, facies $\mathrm{O}$ with old sediments, facies $\mathrm{C} 40 \%$, facies $\mathrm{C} 30 \%$, and facies B $40 \%$.

The overall faunal abundance of 553 ind/ha encompassed mainly, in decreasing order, $258 \mathrm{ind} /$ ha cnidarians (mainly actinians and octocorallians), 180 ind/ha echinoderms (holothurians and crinoids) and 56 ind/ha sponges. There were overall more suspension feeders than deposit feeders and carnivores/scavengers, irrespective of nodule-facies. More specifically, there were more sessile suspension feeders than mobile deposit feeders, mobile carnivores/scavengers, motile suspension feeders or sessile deposit feeders. Preferential habitats for suspension feeders were facies $\mathrm{O}$ with recent sediments and nodule-facies C $10 \%$ on slopes. Among motile suspension feeders, a predominance of actinians was observed, in decreasing order, on facies BP $35 \%$, facies C $30 \%$, facies B $50 \%$, facies C $15 \%$, and on facies $\mathrm{O}$. The preferential habitat for deposit feeders, mainly echinoids and holothurians, was facies C $10 \%$.

Overall, taxa are more abundant on, in decreasing order, the following facies,: facies $\mathrm{C} 10 \%$ on slopes $>15^{\circ}$, facies $\mathrm{O}$ in recent sediments, facies C $15 \%$, facies C $20 \%$, facies BP $35 \%$, facies C 
TABLE 1 | Nodules-facies classification based on visual identification from samples and imagery (Voisset and Hein, 1978; Hoffert and Saget, 2004).

\begin{tabular}{|c|c|c|c|c|c|}
\hline Nodule-facies & A & BP & B & C & $\mathrm{C}+$ \\
\hline \multicolumn{6}{|l|}{ CRITERIA } \\
\hline $\begin{array}{l}\text { Degree of burial } \\
(\%)\end{array}$ & 0 & $0-30$ & $30-60$ & $60-100$ & $30-60$ \\
\hline $\begin{array}{l}\text { Est. average } \\
\text { diameter in cm }\end{array}$ & $<2-10$ & $2.5-4.5$ & $2.5-10$ & $2.5->15$ & $2.5-7.5$ \\
\hline Morphology & $\begin{array}{l}\text { Spherical, } \\
\text { polylobate }\end{array}$ & $\begin{array}{l}\text { Heterogen } \\
\text { fragments }\end{array}$ & $\begin{array}{l}\text { Disk, } \\
\text { ellipsoid } \\
\text { polylobate, } \\
\text { fragments }\end{array}$ & $\begin{array}{l}\text { Spherical, } \\
\text { ellipsoid }\end{array}$ & $\begin{array}{l}\text { Spherical, } \\
\text { ellipsoid } \\
\text { fragments }\end{array}$ \\
\hline $\begin{array}{l}\text { Aspect of upper } \\
\text { surface }\end{array}$ & $\begin{array}{l}\text { Very } \\
\text { smooth }\end{array}$ & Smooth & $\begin{array}{l}\text { Smooth, } \\
\text { some } \\
\text { granular }\end{array}$ & $\begin{array}{l}\text { Very } \\
\text { hummocky } \\
\text { equatorial } \\
\text { thickening }\end{array}$ & $\begin{array}{l}\text { Hummocky } \\
\text { Granular } \\
\text { some } \\
\text { smooth }\end{array}$ \\
\hline $\begin{array}{l}\text { Sediment on } \\
\text { upper surface }\end{array}$ & No & Some & Some & A lot & Yes \\
\hline $\begin{array}{l}\text { Aggregated } \\
\text { nodules }\end{array}$ & $\begin{array}{l}\text { Very } \\
\text { frequent }\end{array}$ & $\begin{array}{l}\text { Very } \\
\text { frequent }\end{array}$ & Never & Never & Never \\
\hline $\begin{array}{l}\text { Density on the } \\
\text { seabed }\end{array}$ & $\begin{array}{l}\text { High } \\
(30-50 \%)\end{array}$ & $\begin{array}{l}\text { High } \\
(35-50 \%)\end{array}$ & $\begin{array}{l}\text { High } \\
(40-50 \%)\end{array}$ & $\begin{array}{l}\text { Low } \\
\text { (5-20\%) }\end{array}$ & $\begin{array}{l}\text { Medium } \\
(20-40 \%)\end{array}$ \\
\hline
\end{tabular}

$2-5 \%$, facies B 50\%, facies BP 50\%, facies $\mathrm{O}$ in old sediments, facies C $40 \%$, facies C 30\%, and facies B 40\% (Figure 5).

Some phyla prevail on specific facies, e.g., cnidarians, echinoderms and sponges, on facies C $10 \%$ and facies C $30 \%$ on slopes. The Echiurian bonnelid worms, Jacobia birsteini, have been identified in association to large mounds (more than $2 \mathrm{~m}$ long, $80 \mathrm{~cm}$ wide and $50 \mathrm{~cm}$ high) (Tilot, 1988, 1995, 2006a) which evidence suggests to increase turbulence, induce an exchange with the interstitial water in galleries and influence the depth of nodule cover. They are present, at densities of up to 16 ind/ha, mainly in facies B40\%, facies B50\%, facies BP35\%, and facies $\mathrm{BP} 35 \%$. On videos from the Nautile their density was much higher (44 ind/ha), due probably to better viewing conditions (lenses, distance and angle) and the patchiness of populations. There are 13 preferential habitats which can be ranked according to nodule coverage and slope $>15^{\circ}$ as shown in Figure 5. Some facies in NIXO 45 have exclusive taxa such as facies $\mathrm{O}$ with ancient sediments (Oligocene to Miocene) and facies C 15\%. Habitat heterogeneity was found to be the main factor structuring the distribution of megafaunal assemblages at different scales. In addition there is a marked patchiness in the distribution of specific megafaunal taxa, e.g., of the actinid Sincyonis tuberculata which aggregates in great densities in sampling areas above $1,600 \mathrm{~m}^{2}$ on facies $C$ and above $800 \mathrm{~m}^{2}$ on facies $\mathrm{O}$ according to the Levis, David and Moore indexes and Fisher's coefficient. When comparing data collected with the autonomous unmanned Epaulard and the manned submersible Nautile, the same overall mean abundances (508 ind/ha) and abundances of individual phyla were observed, e.g., cnidarians at $228 \mathrm{ind} / \mathrm{ha}$ and echinoderms at $132 \mathrm{ind} / \mathrm{ha}$.

Given the more detailed work undertaken within NIXO 45 it was possible to distinguish the different megafaunal assemblages characteristic of the main facies within this area (see also Tilot,
1992, 2006a). These were elucidated using multi-dimensional scaling (Figures 6, 7) as follows:

\section{Facies $\mathrm{O}$ on Ancient Sediments}

This facies is characterized by a majority of suspension feeders, notably sponges Pheronema sp., ringed hexactinellids Cladorhiza sp. (which were most abundant on this facies), octocorallians of the families Primnoidae and Isididae, fixed crinoids of the family Hyocrinidae, and actinians from the families Hormathiidae, Actinoscyphiidae and Amphianthidae (with Amphianthus bathybium prevailing). Detritus feeders present are mainly asteroids from the family Pterasteridae, and the holothurians Synallactes aenigma and Benthodytes lingua. Taxa unique to this facies are sponges of the family Cladorhizidae, sedentary polychaetes with characteristic rounded mounds, asteroids. Hymenaster violaceus, holothurians Benthodytes lingua, holothurians, gastropods Pterotracheidae and Liparid fish.

\section{Facies $\mathrm{O}$ on Recent Sediments}

This facies is characterized among suspension feeders mainly by octocorallians, among detritus feeders by isopods of the family Munnopsidae and asteroids of the family Porcellenasteridae, and among carnivores by Ophidioid and Ipnopid fishes. A particular form of bioturbation, the "witch ring" (Heezen and Hollister, 1971), associated with polychaete worms, is typically abundant on this facies. Unique to this facies are the holothurians Psychropotes longicauda, the siphonophores Physonectes and sedentary polychaetes of the family Cirratulidae.

\section{Facies C 5-10\%}

This facies is characterized by a high abundance of suspension feeders including octocoralliarids of the families Isididae, Primnoidae and Umbellulidae, corallimorpharids of the family Sideractiidae (Nectatis singularis has a high abundance only on this facies) and hexactinellid sponges of the family Hyalonematidae among which Hyalonema sp., Poecillastra sp., Phakellia sp., and Esperiopsis sp. are the most abundant. Detritus feeders are mainly the holothurians Peniagone gracilis, Mesothuria murrayi, Paelopatides sp., Pannychia moseleyi and Enypiastes eximia, the echinoids Plesiodiadema globulosum, isopods of the family Munnopsidae and the sipunculids Nephasoma elisae. Carnivores are represented by an Ophidioid fish, a jellyfish of the family Trachynemidae and the decapod Plesiopenaeus sp. Unique to this facies are alveolate hexactinellid sponges, the demosponges Phakellia sp., bivalves of the family Vesicomyidae and the decapods Plesiopenaeus sp.

\section{Facies C 15-25\% Including Slopes $>15^{\circ}$}

This facies is characterized by a high diversity; it is dominated by the suspension feeding actinids Liponema spp., Actinernus verrill, Bolocera sp., Actinoscyphia sp., the sponges Caulophacus sp. (which are most abundant on this facies) and Poecillastra sp., ring- or dish-shaped hexactinellids of the family Rosselidae, Euretidae, and Cladorhizidae, Cornucopia sp. (on slopes), crinoids of the family Antedonidae and polychaetes of the family Sabellidae. Detritus feeders are mostly echinoids of the family Aeropsidae, the holothurians Peniagone vitrea, Meseres macdonaldi, Benthodytes sp., and an asterid of the 


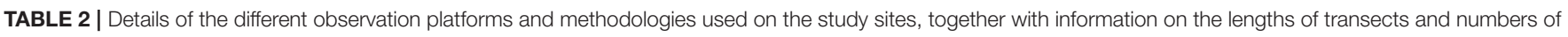
images captured.

\section{Equipment}

\section{Photo and video sampling}

The free sampler "ED1," a camera coupled to a sampling device, was conceived by the EGMO company. The camera allows a slightly oblique angle of shot in relation to the vertical, photographing an area of about $1 \mathrm{~m}^{2}$.
A total of 3,213 stations (or photographs) were taken in the CCZ during different campaigns from 1975 onwards and these photographs were examined for this study.
The "troika" is a towed suprabenthic camera sleigh, $2.5 \times 1 \times 1.6 \mathrm{~m}$, developed by Commander J.Y. Cousteau, equipped with 2 Benthos "372" cameras, a Hydroproducts SDA video camera, an Edgerton 382 flash, and a $200 \mathrm{~W}$ spotlight. The area covered by photographs is from 1 to $2.5 \mathrm{~m}^{2}$ and the definition allows identification of objects $>$ than $5 \mathrm{~cm}$
The troika was used in the NORIA area, at sites A and B of the COPANO cruise in 1979 in the $\mathrm{CCZ}$ (site $\mathrm{A}: 132^{\circ} 44^{\prime} \mathrm{W}-16^{\circ} 34^{\prime} \mathrm{N}$; site B: $133^{\circ} 20^{\prime} \mathrm{W}-14^{\circ} 30^{\prime} \mathrm{N}$ ). The interval between shots was 6 seconds. A combined total of 2,400 photographs taken at these 2 sites were analyzed in this study.

\section{The "R.A.I.E” (Remorquage Abyssal d'Instruments pour l'Exploration)} (Figure 3) was developed for Ifremer to investigate polymetallic deposits on the seabed. It is equipped with two cameras, one Benthos 377 cameras $(28 \mathrm{~mm}$ and $16 \mathrm{~mm}$ ) able to take 3,800 shots and one Benthos 387 . The angle of view is subvertical, inclined at $10^{\circ}$, to avoid recording the ballast in the photographic field. For an altitude of $3 \mathrm{~m}$, for example, the surface that is photographed is 7 $\mathrm{m}^{2}$. The interval between shots in the version of "R.A.I.E." used in the nodule zones is of $16 \mathrm{~s}$.

The "Épaulard" (Figure 3) is an autonomous unmanned submersible developed by Ifremer. This submersible is $4 \times 2 \times 1.1 \mathrm{~m}$ in size and is piloted from the surface by acoustic controls to a depth of $6,000 \mathrm{~m}$. During survey work the "Épaulard" is maintained at a height about $5 \mathrm{~m}$ from the ocean floor, so that the photographs obtained each cover about $25 \mathrm{~m}^{2}$. It is equipped with a Benthos 377 camera capable of taking 5,000 photographs at a rate of one every $5 \mathrm{~s}$.

The "Nautile" (Figure $\mathbf{3}$ ) is an autonomous manned submersible, $8 \times 2.7 \times$ $3.45 \mathrm{~m}$, developed by Ifremer and the D.T.C.N. It is capable of descending to $6,000 \mathrm{~m}$ and moving at a maximum speed of 2.5 knots during a dive of up to $13 \mathrm{~h}$. It is equipped with a video camera, two photographic cameras and six searchlights $(3,000 \mathrm{~W})$. The width of the field covered is about $2 \mathrm{~m}$. Wakefield and Genin (1987) enabled to adapt a Canadian Perspective grid. The cameras can be oriented, generally one oblique and one vertical.
The "Deep Tow Instrumentation System," developed for the Scripps Institute of oceanography in the USA, is a metal chassis towed near the seabed. A $35 \mathrm{~mm}$ video camera and two Benthos cameras with $50 \mathrm{~mm}$ (wide angle) and $70 \mathrm{~mm}$ (telephoto) objective lenses. During the ECHO I cruise in June 1983, the height of the camera above the floor was $10 \mathrm{~m}$. As this was often too high for the recognition of the fauna, the $70 \mathrm{~mm}$ telephoto objective was used to reveal greater detail.

The Russian towed cameras MIR-1 and NEPTUN, as well as a modified ORETECH (Ocean Research Equipment Technology Inc., USA) towed deep-sea camera system, were used during a benthic impact assessment experiment, conducted by the Interoceanmetal Joint Organization (IOM) in the CCZ in 1994-1997, the impact being generated by the Deep Sea Sediment Resuspension System (DSSRS).
Close to 76,200 photographs, relating to a total distance of 1,447 km and covering about 144 ha, were taken by the "R.A.I.E." in the NORIA zone. In the NIXO 45 site, a random selection of 48,100 photographs, covering an area of about 91 ha, collected by the "Epaulard" and the RAIE was analyzed in sets of 200 photographs each set covering about 3,800 $\mathrm{m}^{2}$. In the NIXO 41 site, 18,000 photographs were collected during the SEANOD 2 cruise in Dec-Jan 1980-1981, along $274 \mathrm{~km}$ of transect, resulting in analysis of 34.2 ha of the seafloor. taken since 1975 along $227 \mathrm{~km}$ of transect and covering about 160 ha of the NORIA area. In the NIXO 45 site, a random selection of 48,100 photographs, covering an area of about 91 ha, were collected by the "Epaulard" and the "R.A.I.E." and have been analyzed in sets of 200 photographs, each covering about 3,800 $\mathrm{m}^{2}$.

During the NIXONAUT cruise in 1988, the "Nautile" was able to make 16 dives over the nodule zones, in particular NIXO 45, resulting in a total of $55 \mathrm{~h}$ of video footage and 2,090 photographs of the seabed in the CCZ that were examined in this study.
The present study has involved detailed examination of 84,937 photographs,

Resuspension System (DSSRS).

(2)

A total of 14 DSSRS tows were carried out within a site of $1.5 \times 2.0 \mathrm{~km}$, and the
impact observed from deep-sea camera tows and sediment samples. In
October 1994, five transects $(7.13-10.13 \mathrm{~km}$ long) were surveyed with the
MIR-1, resulting in a total of 3,523 technically acceptable frames; in July 1995 ,
five transects $(1.91-2.94 \mathrm{~km})$ were surveyed with the NEPTUN yielding a total of
1,038 frames; and in April 1997, four transects $(3.0-10.3 \mathrm{~km})$ were surveyed with
the modified ORETECH, producing a total of 3,299 frames (Radziejewska and
Stoyanova, 2000).
During the ECHO I expedition (Spiess et al., 1987), the Deep Tow made 11 photographic transects and collected about 5,500 photographs over about $12,400 \mathrm{~m}^{2}$ of ocean floor, analysis of which is included in this present study. family Brisingidae with 10 arms and the peracarid Cumaceans. The carnivores present are mostly decapods Nematocarcinus sp., archaeogastropods and siphonophores of the families Rhodaliidae and Bithitidae, such as Typhlonus sp. Unique to this facies are sponges Hyalonema sp., members of the family Caulophacidae, the siphonophores Physonectes, Chiroteuthid cephalopods, Galatheids with a rounded rostrum, neogastropods of the family Turridae, polychaetes of the family Polynoidae or Aphroditidae and the fish Coryphaenoides yaquinae.

\section{Facies C $30-40 \%$}

This facies is characterized mainly by the suspension feeding sponges, Euplectella sp. and the dark ophiuroids, Ophiomusium sp. Common detritus feeders are the holthurians Peniagone intermedia, and, in particular, the swimming holothurians Enypniastes eximia. Carnivores are represented by polychaetes of the family Hesionidae and Aphroditidae. Unique to this facies are the cephalopods Benthesicymus sp., jellyfish of the family Nausithoidae, the holothurians Orphnurgus sp. and Amperima 


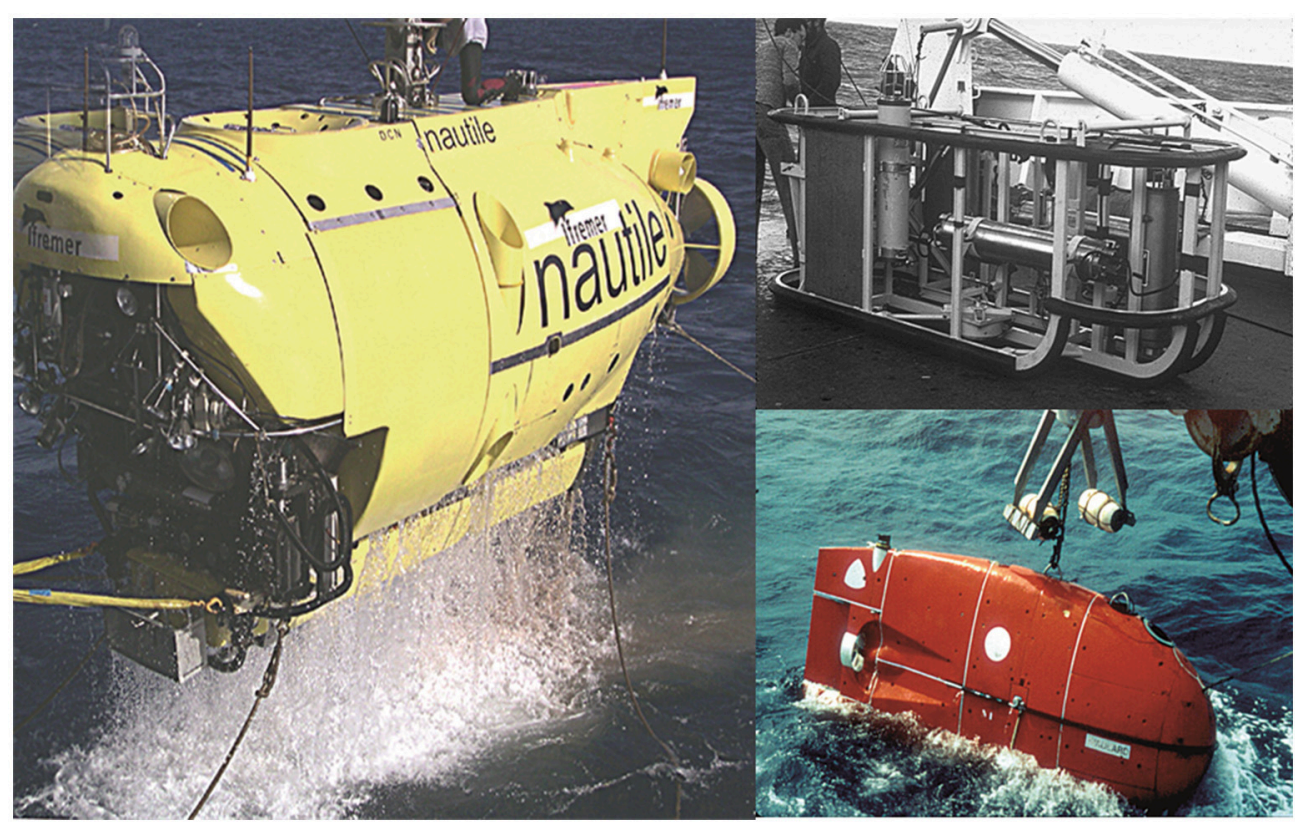

FIGURE 3 | Principle platforms deployed during exploration and sampling of the French NORIA area. (Left) Manned submersible "Nautile" (Top right) Towed "R.A.I.E"; (Bottom right) Remote controlled submersible "Epaulard" (@ all figures IFREMER) http://unesdoc.unesco.org/images/0014/001495/149556f.pdf, volume 1, Figures 20, 28, 30 (Tilot, 2006a), http://unesdoc.unesco.org/images/0014/001495/149556e.pdf\#223, volume 3, Appendix I, Figures 10, 11 (Tilot, 2010b).

naresi and an unknown, about $30 \mathrm{~cm}$ diameter, apparently freeliving ascidian.

\section{Facies B (40-50\%)}

This facies is characterized by a dominance of suspension feeders over detritus feeders. The suspension feeders are mostly the antipatharids Bathypates patula and Bathypates lyra and the brisingids Freyella sp. The detritus feeders are mostly the holothurians Psychronaetes hanseni and Benthodytes typica and the asteroids Hymenaster sp. Also found are aggregations of the actinids Sincyonis tuberculata and of swimming aphroditid polychaetes. Unique to this facies are octocoralliarids of the family Umbellulidae, the antipatharids Schizpathes crassa and holothurians of the family Deimatidae, Deima validum.

\section{Facies BP (35-50\%)}

This facies is characterized by the prevalence of fixed suspension feeders including vase-shaped sponges, Poecillastra sp., which are most abundant on this facies, the actinids Bolocera sp., Sincyonis tuberculata and Actinoscyphia, and the ophiuroids, Ophiomusium armatum. Detritus feeders are mainly the holothurians Synallactes aenigma, Synallactes profundi, Peniagone leander, and Benthodytes sp. (e.g., B. incerta), while the carnivores are mostly polynoid polychaetes. Unique to this facies is a two-horned shaped Hexactinellid sponge.

\section{Facies A (30\%)}

This facies, which in fact is mainly present in NIXO 41, is characterized by a dominance of suspension feeders over detritus feeders, not due to an abundance of cnidarians as on other facies, but to the high abundance of the ophiuroids,
Ophiomusium armatum. Other echinoderms present include the holuthurians Synallactes profundi, Deima validum, Benthodytes sp., Mesothuria murrayi, Peniagone leander, and Psychronaetes hanseni, the echinoids Plesiodiadema globulosum, and the crinoids Fariometra parvula. Cnidarians are mainly represented by actinians (Actinernus verrill, Sincyonis tuberculata), and by the sponges Pheronema sp. and other hexactinellids. The bonellid worms Jacobia birsteini are particularly abundant on this facies. Unique to the facies are the holothurians Peniagone vitrea and Amperima rosea.

\section{Facies RCVO (Rocky, with Carbonate Bars and Volcanic Outcrops)}

This facies has a much lower diversity of megafauna, consisting mostly of suspension feeding octocorallians, with, in decreasing order of abundance, sponges (Cornucopia sp.), actinians and crinoids. Very few detritus feeders or carnivores are evident.

\section{NIXO 41}

NIXO 41 appeared to be very similar to NIXO 45 in terms of taxonomic richness and faunal abundance, despite the different methods and different platforms employed (different towed cameras and the manned submersible Nautile). The two areas showed the same orders of abundance and the same dominance of suspension feeders over deposit feeders and carnivores, whatever the facies, save that NIXO 41 tended to display a prevalence of ophiuroids instead of cnidarians.

Overall, the order of abundance of trophic groups within NIXO 41 may be characterized as sessile deposit feeders > mobile deposit feeders $>$ sessile suspension feeders $>$ mobile carnivores/scavengers $>$ motile suspension feeders. The 


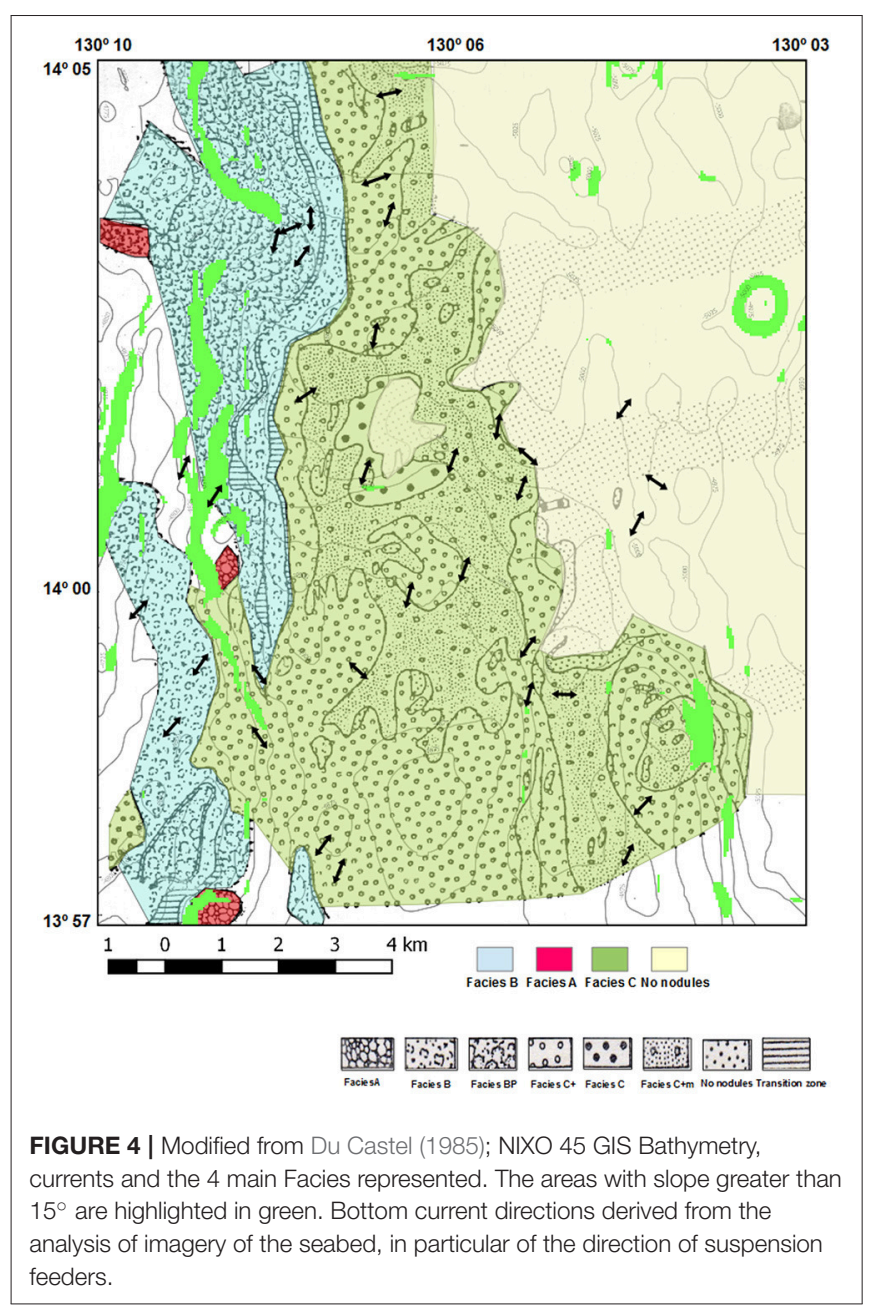

relative abundances of megafauna were, in decreasing order of abundance: sipunculids, echinoderms (mainly echinoids and holothurians), echiurians, sponges, and cnidarians (mainly actinians). No taxon was found to be exclusive to NIXO 41, all the taxa recorded having already been identified in NIXO 45. The overall relative taxonomic richness of the facies was, in decreasing order, facies A $30 \%>$ C $30 \%>$ B $35 \%$. The taxonomic richness, faunal composition, and levels of abundance of individual taxa on facies B 35\% were very similar to those recorded on the same facies in NIXO 45. However Facies C+ 30\% in NIXO 41 had a greater faunal abundance than the same facies in NIXO 45 . The preferred habitat of suspension and deposit feeders was found to be facies C+ 30\% with recent sediments. Facies A 30\% was found to resemble facies B $40 \%$ in NIXO 45 in its population of cnidarians, and sloping facies C $20-40 \%$ in NIXO 45 in having a majority of echinoderms and a relatively high density of sessile deposit feeders, with the bonnelid echiurian worms also present.

\section{ECHO I}

In ECHO I, we recorded 61 taxa over around 25,200 $\mathrm{m}^{2}$ sampled over three nodule-facies, with a higher faunal richness (36 taxa) being recorded on facies C $40 \%$ than on facies B $45 \%$ (23 taxa). Interestingly dredge tracks, produced by pilot-scale mining tests (OMA) in 1978, were still undisturbed and had been partly recolonized by only eight taxa (on facies $\mathrm{O}$ ). There was an overall dominance of deposit feeders over suspension feeders and carnivores/scavengers, and more specifically an overall relative dominance of sessile deposit feeders over mobile deposit feeders, over sessile suspension feeders, over mobile carnivores/scavengers and over motile suspension feeders.

Findings that differed from NIXO 45 and NIXO 41 were that suspension feeders prevailed on facies nodule B $45 \%$ and C $40 \%$ on old sediments, with the most actinians (167 ind/ha) occurring on facies C40\%. Deposit feeders, mostly echinoderms (mainly echinoids and holothurians) were observed to prevail on facies O. Overall the order of abundance of the main taxa was: sipunculids (50 ind/ha), echinoderms (mainly echinoids and holothurians), echiurians, sponges and cnidarians (mainly actinians). The overall predominance of echinoderms, mainly holothurians and echinoids, observed on photographs from ECHO I (taken with a $50 \mathrm{~mm}$ lens) differed from that recorded in NIXO 45, but resembled that recorded in NIXO 41 for facies A $30 \%$ and facies C $30 \%$, except that here echinoderms were mainly represented by ophiuroids instead of holothurians, as in NIXO 45. Deposit feeding sipunculids, echinoids and holothurians, were particularly abundant (332 ind/ha) on facies $\mathrm{O}$ with old sediments.

\section{IOM BIE}

Noticeable at the IOM BIE site was a greater faunal abundance and richness on facies B $45 \%$ and facies C $40 \%$ than on facies $\mathrm{O}$. Overall there were similar numbers of deposit feeders, of suspension feeders and of carnivores/scavengers. However suspension feeders prevailed on the nodule bearing facies, while, as in ECHO I, deposit feeders were slightly more abundant on facies $\mathrm{O}$. On all facies the predominance of echinoderms (mainly holothurians and ophiuroids) over sponges and cnidarians (hydrozoans) was less marked than at the other sites. As in ECHO I, sponges showed a marked preference for nodule facies C $40 \%$, where echiurians were also particularly abundant. The highest diversities were recorded on gently undulating plains and horst slopes, intermediate diversities on horst tops and trough axles, lower diversities on trough slopes, and the lowest diversity on volcanic slopes. That apart, megafauna appeared more abundant on nodules that were diagenically grown i.e. D-Type and $\mathrm{D} 1$ subtype $(\mathrm{Cu}>\mathrm{Ni}>1.2 \%)$ than elsewhere.

\section{Value and Sensitivity Indices for NIXO 45}

Based on data gathered during the survey work in NIXO 45 we assessed the typical (modal) values of each indicator within both Value and Sensitivity Indexes, and hence the value of each indice for each facies. The resulting values are shown in Tables 3A,B. The values support the view that overall type $\mathrm{C}$ facies may be considered the most vulnerable, with type C facies $15-20 \%$ on a slope of $>15^{\circ}$ obtaining very similar scores. 


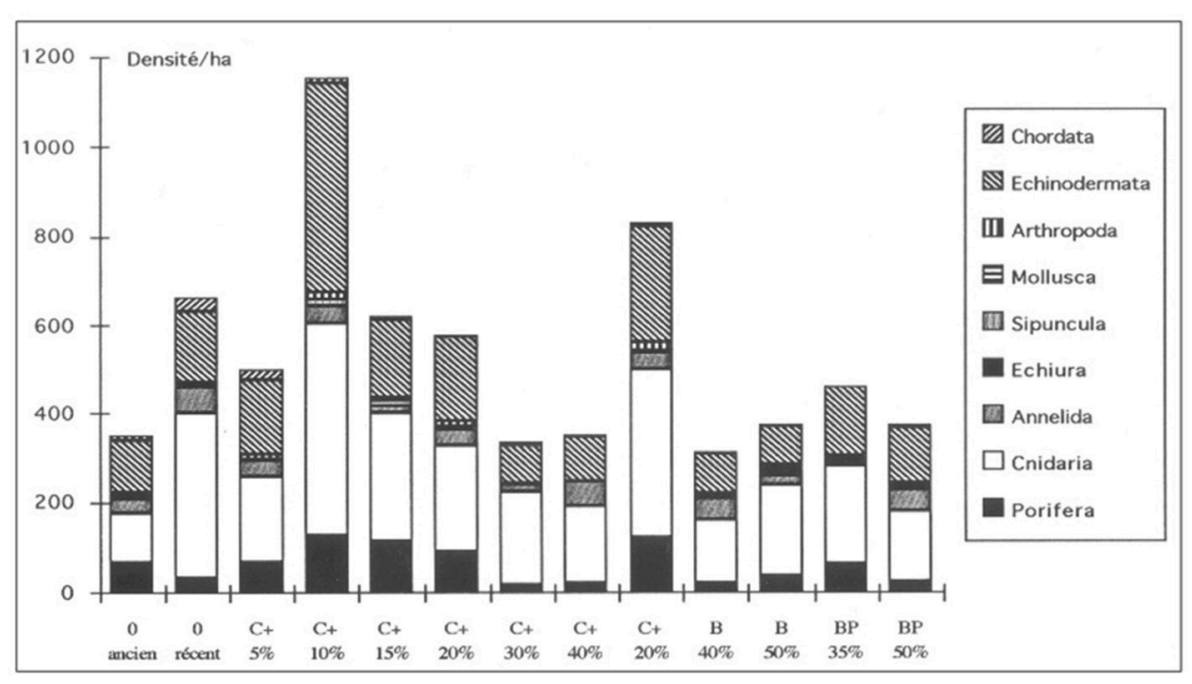

FIGURE 5 | Histogram of the partitioned faunal abundance for each nodule-facies on NIXO 45 (http://unesdoc.unesco.org/images/0014/001495/149556f.pdf, volume 1 Figure 41).

\section{DISCUSSION}

\section{Comparison of Different Observation Platforms}

Unavoidably, different platforms and cameras with different characteristics were used at different sites. Whereas "Epaulard" could provide only a downward looking vertical view, with the manned submersible "Nautile," organisms were observed from an oblique viewpoint and their behavior captured on video with high quality imagery facilitating reliable taxa identification, in particular when coupled with sampling. In this way it was possible to film the complex swimming movements of some holothurians at several meters above the seafloor (Tilot, 1990). Nevertheless, with "Nautile" it was not practical to undertake numerous replicate quantitative surveys as with the others, in particular the Epaulard. Now the ROVs (such as IFREMER's VICTOR 6000) would produce the best results.

In most cases the abundance estimates obtained from the different platforms appeared very similar. However a comparison at NIXO 45 of data obtained using "Nautile" with that obtained using "Epaulard" found that, using "Nautile," between 1.4 and 1.7 times as many suspension feeders and detritus feeders were recorded as with "Épaulard"; it was unclear whether this was because of differences in effective sampling area or observer error. In contrast the overall abundances of carnivores recorded from the two platforms were quite similar, although in part only because greater abundances of errant polychaetes in photographs taken by "Épaulard" were balanced out by "Nautile" recording greater numbers of fish, some of which seemed to be attracted to the submersible. The largest difference observed was the four times as many echiurian burrows observed from "Nautile," since these were much more easily detected given "Nautile's" oblique, wider field of view.
"Épaulard" and "R.A.I.E." were equipped with the same camera and consequently took similar photographs. However "R.A.I.E." was more difficult to maneuver; being towed it was subject to oscillations but better able to explore broken terrain than "Épaulard." The American "Deep Tow Instrumentation System" and the Russian towed cameras MIR-1 and NEPTUN were even more susceptible to oscillation. Deep Tow $50 \mathrm{~mm}$ lens images were often off target, although at other times the higher magnification significantly assisted species identification. But it was not possible to make quantitative comparisons between platforms because they were not available at the same sites, and modest differences in abundance on the same facies were as likely due to differences between sites as between gear. Nevertheless, our experience confirmed conclusions in the literature that the quality of the images does vary with the optical characteristics of the cameras and the construction of the observation system.

\section{Seafloor Topography, Polymetallic Nodule Genesis and Distribution}

The patterns of occurrence of the faunal communities described above needs to be viewed against the topography of the seabed and the processes involved in the formation and growth of the nodules themselves. The CCZ has an average depth of 5,500 m and is mainly composed of abyssal hills, covered by nodule fields interspersed with some nodule-free sediment areas (Hoffert, 2008). The hills, elongated in a north-south direction, run parallel to each other, and have irregular, elliptically domed summits and steep, sometimes escarpment-like sides, although in places rocky substrates and seamounts occur (Menard, 1964; Halbach et al., 1988; Kotlinski, 1998). In the Eastern Equatorial Pacific Ocean, sediment coverage is about $20 \%$ thicker within morphological depressions than on the ridges and, under the influence of sedimentary processes, the contours tend to soften (Shor, 1959). 


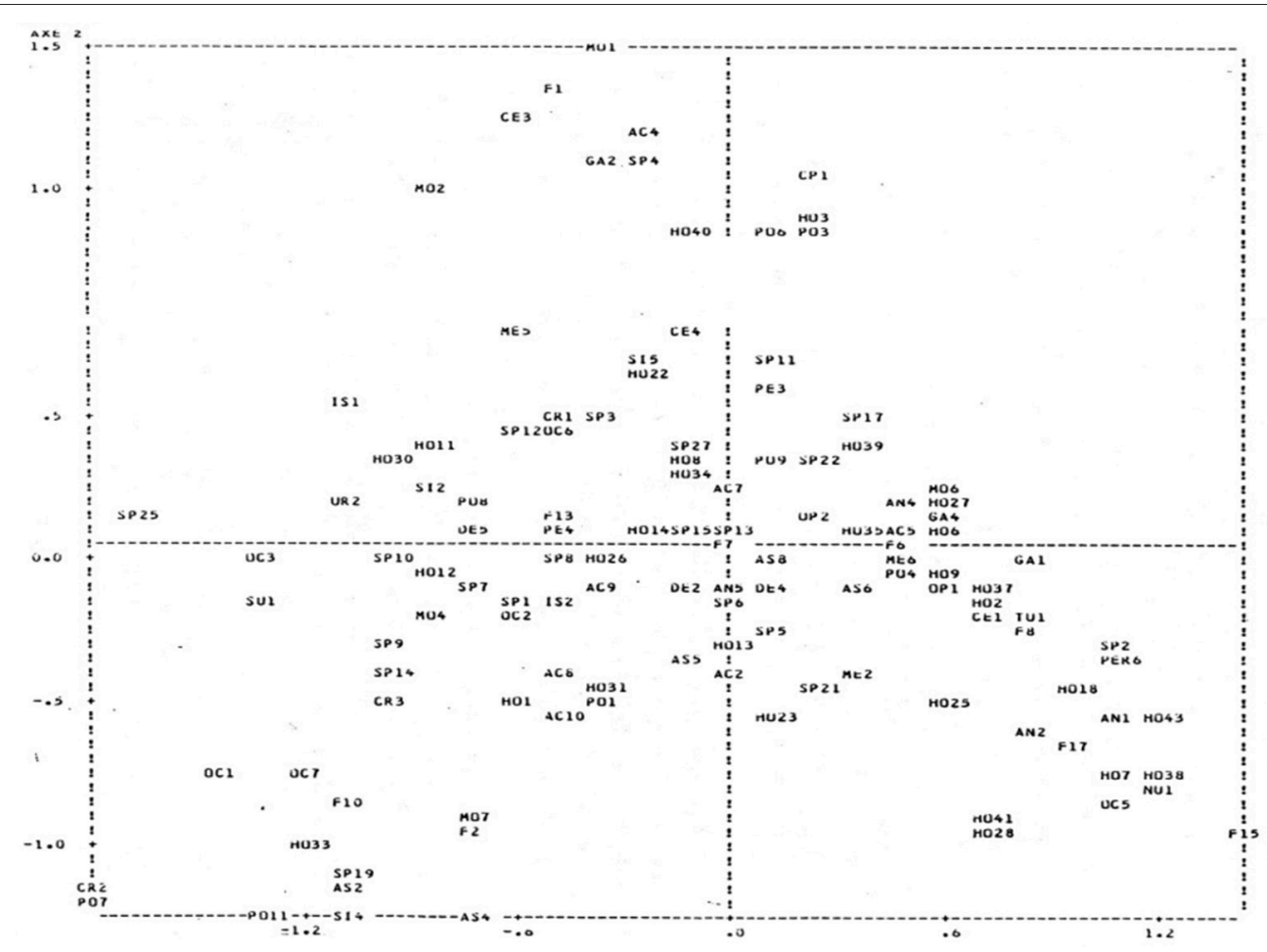

FIGURE 6 | Multi-Dimensional Scaling (MDS) Plot to show the degrees of similarity and difference in distribution patterns of the principal taxa recorded in NIXO 45. (http://unesdoc.unesco.org/images/0014/001495/149556f.pdf, volume 1 Figure 46).

Locally at some sites, such as NIXO 45, seabed morphology comprises horsts and grabens (linear ridges and furrows) that tend to generate stronger currents on slopes that are favored by sessile suspension feeders.

Polymetallic nodules generally lie on the sediment, forming a more or less well developed superficial cover, but can also be buried to several meters within the sediments (Hoffert, 2008). The distribution of nodules seems to be more influenced by the degree of slope than by factors such as longitude, latitude and depth (Friedrich and Plüger, 1974; Wang et al., 2001). The growth of nodules is linked to the migration of manganese across the sediments, and its precipitation and accumulation in the form of concentric layers by oxidation close to the water-sediment interface (Hartmann, 1979). There appear to be two conditions that determine the growth of nodules: the proximity of the CCD and the degree of exposure to currents (von Stackelberg and Beiersdorf, 1991; Hoffert, 2008). The rate of growth of nodules has been estimated by radiochronological methods at several millimeters (4-9 mm) per million years (Harada and Nishida, 1979; Heye, 1988), and the time for reconstitution of nodules at 1 million years for 1-2 mm size nodules (McMurtry, 2001). The role of bioturbation, in particular by deposit feeders, and the role of currents, which are sufficient to transport fine particles, alter chemical properties and reduce the real rate of sedimentation. Both factors have been proposed as important in maintaining the position of the nodules at the sediment surface (Hartmann, 1979; Schneider, 1981; Hoffert, 2008).

\section{The Structure of Faunal Communities in the $\mathrm{CCZ}$}

Taken together, the UNESCO/IOC and ISBA/Kaplan/Nodinaut studies (ISBA, 2008) provide evidence of both intra-regional and within-area variability of the structure of benthic faunal assemblages in the CCZ in relation to variation in biotic and abiotic parameters at different scales of space and time. The data revealed a relatively high taxonomic diversity within all faunal categories, with many species new to science. These findings have been confirmed in the more recent literature (Peterson et al., 1998; Glover et al., 2002; Wang et al., 2010; Janssen et al., 2015; Paterson et al., 2015). Key faunal groups within the CCZ are the cnidarians, echinoderms and sponges among the megafauna, and polychaete worms, nematode worms and protozoan foraminifera among the macrofauna and meiofauna; these taxa represent $>50 \%$ of faunal abundance and species richness in abyssal sediments and display a broad range of ecological and life history types. The faunal assemblages encompass true abyssal species, notable among them Isopoda, Nematoda and Foraminifera and Echinodermata. These conclusions have also been confirmed by more recent studies (Ramirez-Llodra et al., 2011).

Other comparable studies have also supported the view that habitat heterogeneity ("nodule facies," micro-heterogeneity at the nodule level, patches of detritus, biogenic structures and bioturbation), in combination with other factors (bottom currents, sediment chemistry, varying trophic input and 


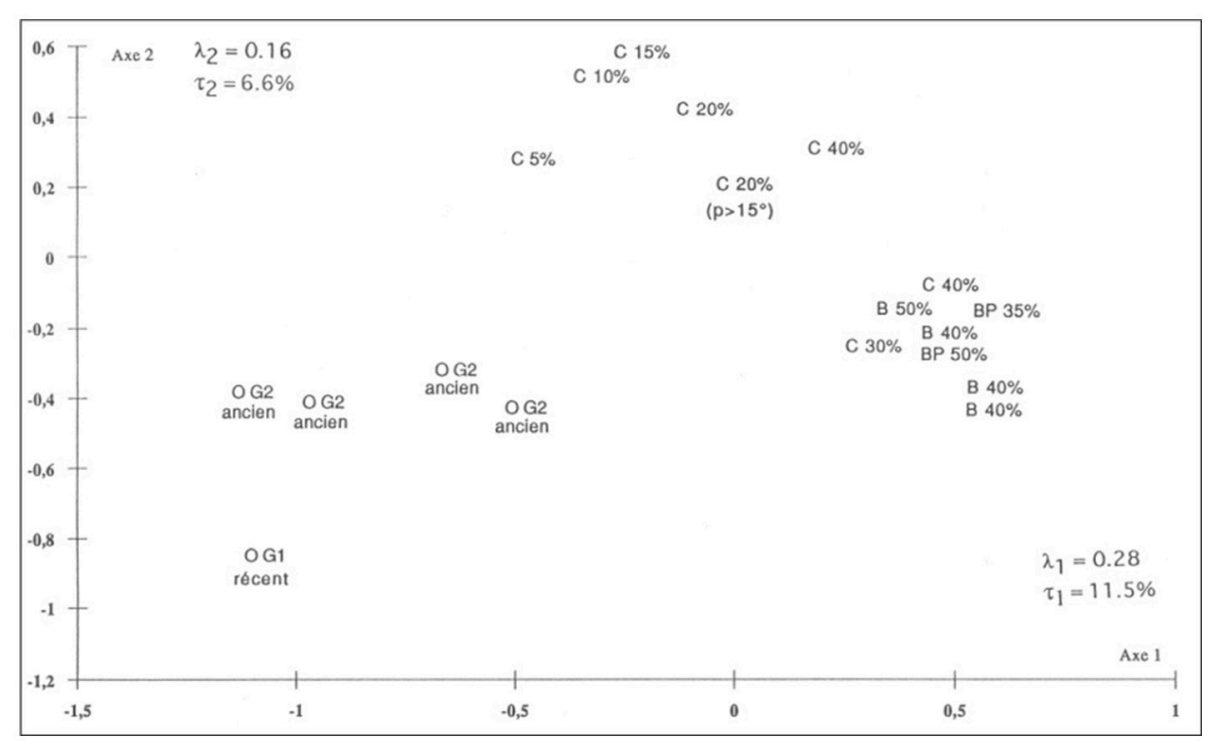

FIGURE 7 | Multi-Dimensional Scaling (MDS) Plot to show the degrees of similarity and difference in the edaphic parameters recorded at each of 20 survey stations within NIXO 45 together with the fascies recorded at each station. (http://unesdoc.unesco.org/images/0014/001495/149556f.pdf, volume 1 Figure 47).

sedimentation rate), are responsible for driving the structure of the epibenthic faunal assemblages. There is clearly a markedly greater abundance and taxonomic richness of megafauna and macrofauna in nodule bearing areas, while meiofauna prefers nodule free areas. This general pattern has been observed not only in the CCZ (Mullineaux, 1987; Morgan, 1991; Radziejewska, 1997; Radziejewska and Stoyanova, 2000; Galeron et al., 2006; ISBA, 2008; Stoyanova, 2008; Gooday et al., 2015; Amon et al., 2016; Vanreusel et al., 2016) but also within the eastern Pacific in the Peru basin, where the nodule crevice fauna has been found to be distinctly different from that living in the sediment in the proximity of the nodules (Tilot, 1989; Thiel et al., 1993).

Nodules clearly provide a distinct habitat for both infaunal communities and for the sessile suspensivore fauna e.g. sponges, actinids, stalked crinoids, octocorallians, sedentary polychaetes, antipatharids, and tunicates, that settle on the nodules. This key conclusion has been supported by Thiel et al. (1993) and Veillette et al. (2007b). In addition, it appears that the nature of the sediments may differ, with softer sediments being located outside of the nodule fields compared to within them. The ISBA/Kaplan/Nodinaut project (ISBA, 2008) also found that megafaunal suspension feeders tend to prevail on nodulecovered areas, while sponges and deposit feeders, particularly holothurians, dominate in the nodule free areas.

That nodule abundance and abiotic factors such as slope, topography and bathymetry, largely determine the abundance and composition of faunal assemblages has been supported in UNESCO/IOC baseline study in which different megafaunal assemblages were found associated with 13 distinctive habitats. However, at a regional scale, the work also provided evidence that (a) there tend to be more suspension feeders at western sites and more deposit feeders at eastern sites, mirroring a gradient in oceanic primary productivity from west to east, and (b) there is an increase in taxonomic richness of megafaunal and macrofaunal assemblages moving from east to west, reflecting a trend of greater substrate heterogeneity at both nodule and facies levels.

As evidenced in Heezen and Hollister (1971) and Kennett (1982), fixed organisms are good indicators of bottom currents. The analysis of the imagery from NIXO 45 found that most suspension feeding assemblages occurred on facies B and C in the eastern and western hills (Tilot, 2006a). Their distribution indicated the general direction of N40-N50 bottom currents. In addition to the main current, water moving in other directions may be observed due to local topography, with secondary currents in contrasting directions resulting within ridge or furrow formations (Flood, 1983). These furrows may be ancient, resulting from the presence of stronger currents in past geological time. The varying near-bed velocity field plays a role in the supply of edible particles to benthic suspension feeders since the horizontal flux of organic seston is a function of the interaction of particles of varying densities with the near-bed velocity field (Muschenheim, 1987). As evidenced in Tilot (2006a), the preferred habitats for suspension feeders are nodule facies vs. facies $\mathrm{O}$, except for facies $\mathrm{O}$ on recent sediments. Suspension feeders are particularly abundant on facies C 5-10\%, C $15-20 \%$ with slope $>15^{\circ}$.

The community structure of the faunal assemblages varies substantially, with a significant turnover in species being evident over a latitudinal range. For foraminifera and polychaetes, the turnover occurs at scales of $1,000-3,000 \mathrm{~km}$ across the CCZ (ISBA/Kaplan/Nodinaut) (Levin et al., 2001; ISBA, 2008). For megafauna, the turnover occurs at a larger scale. In the present study (Tilot, 2006a), the high values of the standard deviations of overall abundances of taxa indicates a high within-site variability, likely the result of the non-random dispersion of fauna widely 
TABLE 3A | "Value Indexes" for NIXO 45 based on results of UNESCO/COI baseline survey (Tilot, 2006a).

\begin{tabular}{|c|c|c|c|c|c|c|c|c|c|}
\hline $\begin{array}{l}\text { VALUE INDEX Facies/criteria } \\
\text { (top number highest value) }\end{array}$ & $\begin{array}{c}\text { O } \\
\text { Old sed }\end{array}$ & $\begin{array}{c}\text { O } \\
\text { Recent sed }\end{array}$ & $\begin{array}{c}\text { A } \\
30-50 \%\end{array}$ & $\begin{array}{c}\text { B } \\
40-50 \%\end{array}$ & $\begin{array}{c}\text { C } \\
5-10 \%\end{array}$ & $\begin{array}{c}\text { C } \\
15-20 \% \text { With } \\
\text { slope }>15^{\circ}\end{array}$ & $\begin{array}{c}\text { C } \\
25-40 \%\end{array}$ & $\begin{array}{c}\text { BP } \\
35-50 \%\end{array}$ & $\begin{array}{c}\text { RCVO } \\
\text { rock-outcrop }\end{array}$ \\
\hline$\%$ nod cover (1-6) & - & - & 3 & 6 & 1 & 2 & 4 & 5 & - \\
\hline Interest for miners (1-3) & - & - & 1 & 3 & 2 & 3 & 3 & 3 & - \\
\hline Slope/escarpments (0-3) & 0 & 0 & 1 & 2 & 0 & 3 & 0 & 1 & 3 \\
\hline Hills (1-3) & 1 & 3 & 2 & 3 & 1 & 2 & 2 & 1 & 1 \\
\hline Plateaux, valleys (0-3) & 0 & 2 & 1 & 3 & 3 & 3 & 3 & 2 & 1 \\
\hline Deeper basins $(0-1)$ & 1 & 0 & 0 & 0 & 0 & 0 & 0 & 0 & 0 \\
\hline Taxon abundance (1-9) & 3 & 7 & 5 & 2 & 9 & 8 & 4 & 6 & 1 \\
\hline Taxon diversity (1-9) & 5 & 8 & 4 & 2 & 9 & 7 & 3 & 6 & 1 \\
\hline Susp feeders (1-9) & 2 & 7 & 3 & 5 & 9 & 8 & 4 & 6 & 1 \\
\hline Detr feeders (1-9) & 5 & 6 & 4 & 3 & 9 & 8 & 7 & 2 & 1 \\
\hline Carnivores (1-9) & 7 & 5 & 1 & 9 & 6 & 3 & 4 & 8 & 2 \\
\hline Echinoderms (1-9) & 3 & 6 & 4 & 2 & 9 & 8 & 7 & 5 & 1 \\
\hline Cnidarians (1-9) & 2 & 6 & 2 & 3 & 9 & 8 & 7 & 4 & 1 \\
\hline Sponges (1-9) & 5 & 3 & 2 & 4 & 7 & 9 & 8 & 6 & 1 \\
\hline Echiurian (1-3) & 2 & 3 & 3 & 3 & 2 & 2 & 3 & 3 & - \\
\hline $\begin{array}{l}\text { Bioturbation (1-3) superficial to } \\
\text { deep }\end{array}$ & 3 & 3 & 2 & 3 & $(1), 3$ & $(1), 3$ & 1 & 2 & - \\
\hline Total & 38 & 59 & 38 & 53 & 80 & 77 & 60 & 60 & 14 \\
\hline Value index/10 & 4 & 6 & 4 & 5 & 8 & 8 & 6 & 6 & 2 \\
\hline
\end{tabular}

"Bioturbation (1-3) was scored as: 1, Surface tracks: (between nodules, circular furrows); 2, Intermediary bioturbation (furrows, lines, imprints); 3, Deep bioturbation (several cm to ms): tumuli, burrows, rosette. The simplified Value Index Score obtained by summing all values and dividing by 10 to give values on a 10-point scale.

reported in the literature (Schneider et al., 1987; Kritzer and Sale, 2010). This phenomenon is particularly evident at the taxon level with e.g., the actinid Sincyonis tuberculata aggregating at greater densities in sampling areas above $1,600 \mathrm{~m}^{2}$ on facies $C$ and above $800 \mathrm{~m}^{2}$ on facies $\mathrm{O}$ according to the Levis, David and Moore indexes and Fisher's coefficient (Tilot, 1992, 2006a).

\section{Primary Productivity, Particulate Organic Carbon Fluxes and Trophic Input}

Primary productivity (NECC) in the CCZ is rather low, ranging from 210 to $327 \mathrm{mg} \mathrm{C} \mathrm{m}^{3} \mathrm{~d}^{-1}$ (Smith and Demopoulos, 2003; Pennington et al., 2006) and in consequence particulate organic carbon fluxes (POCF) range from 0.5 to $1.6 \mathrm{~g} \mathrm{C} \mathrm{m}^{-2} \mathrm{y}^{-1}$, placing the CCZ within the broadly defined mesotrophic abyss, as defined by Hannides and Smith (2003). However, considerable variation in the vertical flow of particles has been described (Karl et al., 1996; Baldwin et al., 1998; Karl, 2002; Smith and Rabouille, 2002) and seems related to seasonal patterns, upwelling and El Niño events (Dymond and Collier, 1988; Ruhl and Smith, 2004). The openness of the ocean system leads to benthic-pelagic coupling that may be not only dynamic but highly variable (Rowe, 1971; Pfannkuche and Lochte, 1993).

This variation in flux results in variable deposition of phytodetritus, often in patches, on the sediment surface (Smith et al., 1997, 2008b; Beaulieu and Smith, 1998; Radziejewska and Stoyanova, 2000; Radziejewska, 2002; Stoyanova, 2008), causing in turn significant changes in the structure of the epibenthic megafaunal assemblages and measurable effects on ecosystem function (Smith et al., 1993; Lauerman et al., 1997; Drazen et al., 1998; Thurston et al., 1998; Danovaro, 2008; Loreau, 2008).

There is evidence however that factors other than the varying vertical deposition of phytodetritus can contribute to trophic input and so influence the structure of the epibenthic assemblages. There is a horizontal contribution to nutritive sediment particles in suspension as a result of currents originating to the west in zones of high primary production. In addition, particular edaphic and hydrological conditions above the bottom layer, perhaps related to the topography of the ocean floor, can favor the collection of nutritive sediment particles. In addition, of course the carcasses of larger pelagic organisms provide a significant input of carbon to benthic food webs (Dayton and Hessler, 1972; Haedrich and Rowe, 1977; Smith and Baco, 2003; Tyler, 2003).

\section{Community Dynamics and Diversity}

Deep sea benthic megafauna are generally small in body size (with some exceptions e.g. bonnelid worms), show low biomass (less than $2 \mathrm{~g} \mathrm{~m}^{-2}$ ) and are extremely delicate, feeding on a thin layer of organic matter at the water-sediment interface. The deep sea megafauna is also characterized by slow metabolic growth, slow maturation, low reproductive potential and low rates of colonization, although compensated for to some extent by greater longevity (Gray, 1977; Gage and Tyler, 1991; Smith and Demopoulos, 2003), all adaptations to extreme environmental 
TABLE 3B | "Sensitivity Index" values for NIXO 45 based on results of UNESCO/COI baseline survey (Tilot, 2006a).

\begin{tabular}{|c|c|c|c|c|c|c|c|c|c|}
\hline $\begin{array}{l}\text { Facies/criteria (top number } \\
\text { highest value) }\end{array}$ & $\begin{array}{c}\text { O } \\
\text { Old sed }\end{array}$ & $\begin{array}{c}\text { O } \\
\text { Recent sed }\end{array}$ & $\begin{array}{c}\text { A } \\
30-50 \%\end{array}$ & $\begin{array}{c}\text { B } \\
40-50 \%\end{array}$ & $\begin{array}{c}C \\
5-10 \%\end{array}$ & $\frac{\text { C }}{15-20 \% \text { slope }>15^{\circ}}$ & $\begin{array}{c}C \\
25-40 \%\end{array}$ & $\begin{array}{c}\text { BP } \\
35-50 \%\end{array}$ & $\begin{array}{c}\text { RCVO } \\
\text { rock-outcrop }\end{array}$ \\
\hline$\%$ nod cover (1-6) Weight 1 & - & - & 3 & 6 & 1 & 2 & 4 & 5 & - \\
\hline Interest for miners (1-3) Weight 0 & - & - & 0 & 0 & 0 & 0 & 0 & 0 & - \\
\hline Slope/escarpments (0-3) Weight 2 & 0 & 0 & 2 & 4 & 0 & 6 & 0 & 2 & 6 \\
\hline Hills (1-3) Weight 2 & 2 & 6 & 4 & 6 & 2 & 2 & 4 & 2 & 2 \\
\hline Plateaux, valleys (0-3) Weight 1 & 0 & 2 & 1 & 3 & 3 & 3 & 3 & 2 & 1 \\
\hline Deeper basins (0-1) Weight 0 & 0 & 0 & 0 & 0 & 0 & 0 & 0 & 0 & 0 \\
\hline Taxon abundance (1-9) Weight 1 & 3 & 7 & 5 & 2 & 9 & 8 & 4 & 6 & 1 \\
\hline Taxon diversity (1-9) Weight 2 & 10 & 16 & 8 & 4 & 18 & 14 & 6 & 12 & 2 \\
\hline Susp feeders (1-9) Weight 2 & 4 & 14 & 6 & 10 & 18 & 16 & 8 & 12 & 2 \\
\hline Detr feeders (1-9) Weight 0 & 0 & 0 & 0 & 0 & 0 & 0 & 0 & 0 & 0 \\
\hline Carnivores (1-9) Weight 1 & 7 & 5 & 1 & 9 & 6 & 3 & 4 & 8 & 2 \\
\hline Echinoderms (1-9) Weight 1 & 3 & 6 & 4 & 2 & 9 & 8 & 7 & 5 & 1 \\
\hline Cnidarians (1-9) Weight 2 & 4 & 12 & 4 & 6 & 18 & 16 & 14 & 8 & 2 \\
\hline Sponges (1-9) Weight 2 & 10 & 6 & 4 & 8 & 14 & 18 & 16 & 12 & 2 \\
\hline Echiurian (1-3) Weight 2 & 4 & 6 & 6 & 6 & 4 & 4 & 6 & 6 & 0 \\
\hline $\begin{array}{l}\text { Bioturbation (1-3) superficial to } \\
\text { deep Weight } 2\end{array}$ & 6 & 6 & 4 & 6 & 4 & 4 & 2 & 4 & 0 \\
\hline Total & 53 & 86 & 52 & 72 & 106 & 104 & 78 & 84 & 21 \\
\hline Sensitivity index/12 & 5 & 9 & 5 & 7 & 11 & 10 & 8 & 8 & 2 \\
\hline
\end{tabular}

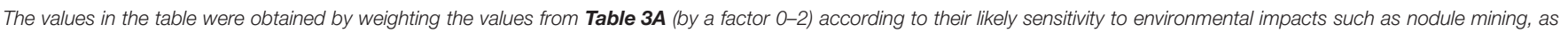

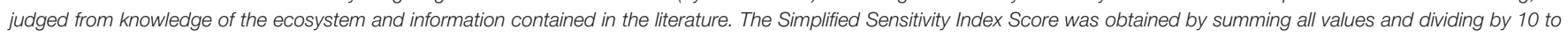
give values on a 12-point scale.

conditions (Rex, 1983). As a result the deep-sea fauna may be viewed as a non-equilibrium community in which, following a patch mosaic model, there develops a dynamic mosaic of microhabitats on which species might specialize (Grassle and Sanders, 1973). The patch mosaic phenomenon enables larvae and juveniles specializing on patches of different sorts to grow until they can compete effectively with other species and so coexist and reproduce (Jumars et al., 1990). Thus, temporal and spatial environmental variability are driving factors within the deep-sea ecosystem (Smith et al., 2001). This variability induces fluctuations in biological processes (Tyler, 1988; Gage and Tyler, 1991; Smith and Kaufmann, 1999; Gooday, 2002) including opportunistic feeding (Billett et al., 1988; Jumars et al., 1990) and rapid community responses to variation at the deep-sea floor (Smith et al., 1986). Thus, contrary to possible expectation, the deep-sea benthos is surprisingly species-rich (Snelgrove and Smith, 2002).

\section{Water Masses, Ocean Circulation, Bottom Currents and Climate Variation Water Masses and Major Currents}

The Pacific Ocean is the largest yet freshest of the three major ocean basins. As a result of its lower salinity, the northern North Pacific shows no deep water formation and only a weakened intermediate water formation (Talley et al., 2011). This is an important factor to be born in mind in relation to deep sea mining, especially given the associated operations (including sediment dispersal) anticipated to take place in midwater. Otherwise the CCZ is dominated by the North Equatorial Current (NEC), which is the broad flow of the subtropical gyre driven westwards by trade winds between 8 and $20^{\circ} \mathrm{N}$ (Fiedler and Talley, 2006). This ocean region, associated with the highly productive equatorial upwelling to the east, is identified as the North Pacific Tropical Gyre province (NPTG) (Longhurst, 2007). Within it, based on the analysis of samples collected by the 2010 Spanish Malaspina Expedition within the area $7^{\circ} \mathrm{N}-20^{\circ} \mathrm{N}$ and $99^{\circ} \mathrm{W}-167^{\circ} \mathrm{W}$, seven separate water masses can be identified at depths between 200 and 4,000 m (Catalá et al., 2015a,b) (Figure 8).

The thermohaline and intermediate waters $(500-1,500 \mathrm{~m})$ in the CCZ present unique features as they undergo excessive aging (Catalá et al., 2015b). This anomaly is associated with (1) the high biological productivity of the area, which exports organic material from the surface to the deep ocean (Feely et al., 2004), and (2) the sluggish circulation of the North Pacific that facilitates organic matter sinking. The high productivity of this area together with the weak sub-thermocline currents results in a pronounced oxygen minimum layer (OML) (Kessler, 2006).

A potentially significant management issue is the desirability of preserving the oldest water masses, located in the North East Pacific between 1,800 and $3,500 \mathrm{~m}$ according to Talley et al. (2011), because of their unique properties, which stem from their perpetual reworking in the deep ocean. They are characterized by a distinct biogeochemistry, and greater molecular diversity, heterogeneity and complexity of dissolved 


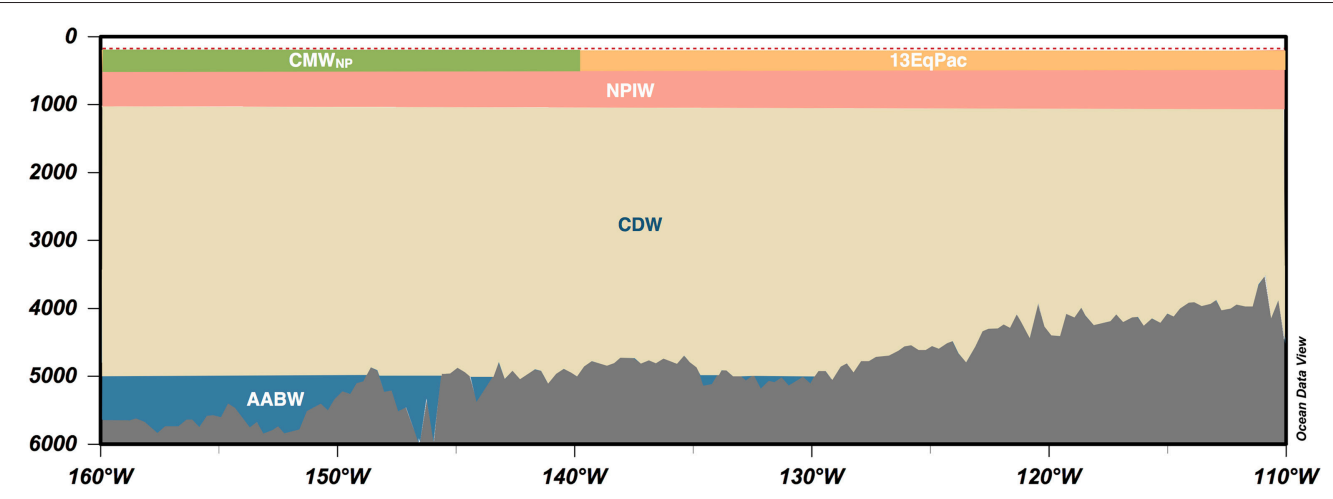

FIGURE 8 | Water masses in the CCZ region. The results are based on the water mass analysis performed in the Malaspina 2010 Circumnavigation (Catala et al. $2015 a, b)$. Only the most abundant water mass for each site was plotted. The dashed red line represents the upper limit of the water mass analysis (200 m). The lower limit of the Malaspina water mass analysis was at 4,000 m. Below this depth, the information has been extracted from Talley et al. (2011). AABW, Antarctic Bottom Water; CDW, Circumpolar Deep Water; NPIW, North Pacific Intermediate Water; CMWNP, North Pacific Central Mode Water; 13EpPac, Equatorial Pacific Central Water (13ㅇ) (Tsuchiya, 1981).

organic matter (Dittmar, 2015). Given the water masses age, its microbial communities are expected to be adapted to these hypoxic and inhospitable conditions, resulting in a different deep-sea microbial biodiversity. This singular biogeochemistry and microbial flora is presumed to have an impact on the nodule ecosystem via the water column food chain and pelagic-benthic transfer to the sediments; it may also influence nodule genesis. These oldest water masses are thus very vulnerable but the impact of deep-sea mining on them remains difficult to quantify.

\section{Eddy Kinetic Energy and Bottom Currents}

The CCZ shows sea-surface elevation variability of $4 \mathrm{~cm}$ or more, the maximum sea-height variability denoting excess eddy kinetic energy at the surface that is then transmitted to the sea floor in water depths exceeding 3,000 $\mathrm{m}$ (Hollister and Nowell, 1991; Kontar and Sokov, 1994). Many regions of the world ocean show evidence of benthic storm activity in which cold currents in the deep ocean accelerate into powerful sediment-transporting events (e.g., Gardner and Sullivan, 1981; Nowell et al., 1982; Hollister and McCave, 1984; Klein, 1987; Quirchmayr, 2015). Bottom currents in the northeastern tropical Pacific are predominantly weak (Shor, 1959), between 2 and $25 \mathrm{~cm} / \mathrm{s}$ (Amos et al., 1977), but the flow is characterized by alternation of periods of stronger, quasi-unidirectional currents and periods of slower water movement (McCartney, 1982; Kontar and Sokov, 1994, 1997). Nevertheless, several hydrographic disturbances, such as changes in deep ocean current or periodic "benthic storms," have been recorded during long-term in situ monitoring (Richardson et al., 1993; Kontar and Sokov, 1994; Aller, 1997); such changes will in turn impinge on the sediment surface itself (Tkatchenko and Radziejewska, 1998).

\section{Climate Variation and Global Warming}

Long-term datasets from the Pacific Ocean basin show that deepsea communities are strongly affected by climate variation (Smith et al., 2009), as are those of the upper-ocean (Levitus et al., 2000; Barnett et al., 2005). Global warming is anticipated to increase stratification while reducing vertical mixing and nutrient exchange from deeper depths (Sarmiento et al., 2004; Behrenfeld et al., 2006); this in turn is expected to reduce primary production and carbon export to the deep-sea (Huisman et al., 2006), thus impacting the deep ocean ecosystem (Glover et al., 2010), including in particular that of the northeast Pacific (McGowan et al., 1998).

\section{Sedimentation Rates and Mixing, Sediment Plumes}

The sediment cover in the CCZ is mainly biogenic, but has been subjected to diagenetic processes to varying extent (Hannides and Smith, 2003; Hoffert, 2008). The surface layer is highly hydrated and can be several $100 \mathrm{~m}$ thick, depending on the age of the crust and prevailing sedimentation rates (Menzies et al., 1973; Kotlinski, 1999). Sedimentation rates in the CCZ are currently assessed to be $0.1-10 \mathrm{~cm}$ per thousand years (Gage and Tyler, 1991; Smith and Demopoulos, 2003). Although the currents are weak $(2-25 \mathrm{~cm} / \mathrm{s})$, they are sufficient to transport fine particles and thus, in places, to reduce the rates of sedimentation. Yet they are too slow to cause the erosion of even lightly consolidated sediments (Hoffert, 2008). This explains why in ECHO I dredge tracks produced in 1978 are still visible over 30 years later (Tilot, 1991, 2006a; ISBA, 2008).

The environmental impact studies that have been conducted on nodule ecosystems in the CCZ, the Indian Ocean and the Peru basin (e.g., Amos et al., 1977; Ozturgut et al., 1980; Tilot, 1989; Foell et al., 1990; Thiel et al., 1991, 2001; Bluhm et al., 1995; Fukushima, 1995; Tkatchenko et al., 1996; Radziejewska, 1997; Schriever et al., 1997; Trueblood et al., 1997; Shirayama, 1999; Fukushima et al., 2000; Chung et al., 2001; Oebius et al., 2001; Sharma et al., 2001) mostly focused on alterations to the sediment-nodule interface and impacts to epibenthic faunal communities over very localized areas, compared to the size and the number of areas to be mined. Several reviews (e.g., Smith, 1999; Sharma, 2015; Jones et al., 2017) concluded that there is a lack of information on the potential impact of sediment burial 
at the scale of the CCZ and that there would be considerable long-term negative effects on the ecosystem.

These arise because, according to Sharma (2015), for every ton of manganese nodule mined, $2.5-0.5$ tons of sediment will be resuspended. Adjacent areas will obviously experience the highest sedimentation rates, but sediment plumes will remain in suspension over long periods and also travel laterally. It is considered that significant sediment loads will clog the filter feeding apparatus of most benthic fauna. Hannides and Smith (2003) estimate that the mining proposed would severely affect benthic communities over $20,000-45,000 \mathrm{~km}^{2}$ of seabed, with resettlement of up to $95 \%$ of the sediment particles released within a period of 3-14 years, depending on the depth of release (Rolinski et al., 2001). That this is so can be appreciated if one considers that even with a current as low as $1 \mathrm{~cm}$ per second, water-borne sediment would travel more than $3,000 \mathrm{~km}$ within a period of 10 years. Even while still suspended in the water column, the sediment plume is anticipated to have various effects depending on the particular water masses involved.

\section{Ecological Characteristics and Sensitivity Impacts}

Given the foregoing it appears that the ecological characteristics of the nodule ecosystem within the CCZ, and their sensitivity to natural and anthropogenic impacts may be summarized as in Table 4. This indicates the great sensitivity of much of the fauna to the impacts to be expected from nodule mining. This conclusion in turn highlights the need to manage operations so as to minimize disturbance, an issue we consider in the next sections.

\section{Options for Management of the Impacts of Deep Sea Mining The Need for Reference Areas and Tridimensional Management}

The study of environmental and edaphic conditions expands our understanding of the role of suprabenthic faunal communities in the nodule ecosystem in the CCZ, beyond that developed previously during the UNESCO/IOC and ISBA/Kaplan/Nodinaut studies and elsewhere (Amos et al., 1977; Aller, 1997; Glover and Smith, 2003). The associations between different functional assemblages and particular biotopes, especially within the different nodule facies, reflect the critical factors that drive the species population dynamics; these will likely include environmental heterogeneity, sediment loads and current variability and strength, as well as biotic factors. This dependence of the biological community on precise physical environment needs to be borne in mind when considering the management of such physically driven biotopes, as does the fact that these environments are one of the world's few that remain relatively pristine (Tilot, 2010a). The changes to the seabed and overlying water-column brought about by the mining activity will inevitably impact the different benthic communities present. Further both natural impacts (natural climate variation, benthic storms, El Niño events...) and anthropogenic disturbances (pollution, fishing, seabed mining, oil and gas extraction, disposal of wastes...) generally result in degradation and homogenization of habitats across broad areas (Glover and Smith, 2003; Thiel, 2003; Smith et al., 2008a).

Unfortunately, unlike fisheries for example, polymetallic nodule mining cannot be managed as a sustainable activity, since the reconstitution of nodules following removal, and the restoration of the nodule ecosystem, if ever possible, will take several million years, based on measured rates of nodule formation and growth (Ghosh and Mukhopadhyay, 2000; McMurtry, 2001). Further, commercial nodule mining is envisioned to be the largest-scale human activity ever to affect the deep sea, most probably taking place at a regional scale over an area of more than 3 million $\mathrm{km}^{2}$ of the deep sea floor. The processes will impact not only the benthos, but also the water column and the surface of the ocean (and even the layer of air over the ocean), at a global regional scale. Thus, faunal communities particular to the nodule ecosystem may even be threatened with extinction.

The temporal and spatial scales of disturbances will naturally determine whether these habitats are able to sustain themselves or change to the extent that the original pristine state can never be recovered (Gundersen and Pritchard, 2002; Berkes et al., 2003; Gollner et al., 2017). The extent of impacts will have crucial consequences for management, since it is easier to repair a damaged ecosystem than restore, it once destroyed. During impact and post-impact phases, changes in species composition of the benthos almost invariably occur, often favoring short-lived species that can quickly colonize after the disturbances (Hughes et al., 2003). Subsequently alternate ecosystem states may be maintained through density-dependent mortality effects (e.g., owing to altered predator-prey ratios) or as a result of populations failing to achieve density thresholds required for reproductive success (Cury and Shannon, 2004). In the face of such threats to ecosystem viability, the critical need to safeguard all aspects of marine as well terrestrial biodiversity has been widely recognized by both scientists and decision takers, and enshrined within a suite of international agreements, in particular, the Convention on Biological Diversity and the United Nations Convention on the Law of the Sea. An emerging multidisciplinary consensus stresses the importance of assessing and actively promoting ecosystem resilience (Peterson et al., 1998; Folke et al., 2004), to achieve which it will be key to establish deep-sea reference areas in the proximity of the deep-sea mining areas.

In addition, it is now widely accepted that for the effective protection of marine biodiversity and marine resources the establishment of marine protected areas (MPAs) is essential (Tundi Agardy, 1994; Margules and Pressey, 2000; Roberts et al., 2001; Edgar et al., 2007). The numbers and extent of MPAs has increased rapidly over recent decades, with a target of protecting $10 \%$ of ocean areas incorporated in the Convention on Biological Diversity and a target of 30\% recommended by the 2014 Sydney World Parks Congress. While almost all earlier MPAs were designated in coastal waters and within the territorial waters of individual nations or territories, increasingly a move toward declaring large open ocean and high seas protected areas is evident (Corrigan and Kershaw, 2008; Game et al., 2009; O'Leary et al., 2012; Gianni et al., 2016). 
TABLE 4 | Table summarizing the potential effects of nodule exploitation on all aspects of the environment and ecology of the CCZ.

\section{General ecological characteristics \\ Sensitivity to natural and anthropogenic impacts}

Primary productivity, particulate organic carbon flux (POCF), trophic input to the seabed

More sensitive. There will be a cumulative impact of natural and anthropogenic activities at the surface, in the water column and on the seabed. Recovery rates need to be assessed for each stage and when cumulated.

Biological features: biomass, respiration, reproduction, growth recolonization

More sensitive. These processes will show only a slow recovery even if there is some survival. Recent research evidences rapid adaptation to variable trophic input as a result of opportunistic behavior of some taxa, but this represents a change in ecology. It is desirable to test their response to DSM impact and identify thresholds for survivorship and reorganization of food chains.

Biodiversity: taxonomic richness, taxon abundance and distribution at different temporal and spatial scales

Highly sensitive. Although true species diversity is poorly known since populations are undersampled, the high within-site taxonomic diversity observed here implies serious consequences for attempts to conserve the biodiversity of the CCZ. Many species are new to science and therefore need to be protected from extinction until their conservation status is determined. Further various biotic and abiotic parameters influence the species distribution patterns at both regional and intra-area scales. In particular biodiversity and abundance of megafauna is greater on nodule areas vs. nodule free areas, in particular in facies C 5-20\% nodules + slopes $>15 \%$. Also, information is lacking on sensitivity to impacts of recolonization across different spatial-scale dependence.

Ambient parameters: temperature, light, pressure

Temperature is $1-4^{\circ} \mathrm{C}$, pressure increases with depth to 500 bar at $5,000 \mathrm{~m}$; there is no light and very low nutrient levels, although many organisms produce bioluminescence. Organisms may therefore be functioning at the limits of their physiology and have limited ability to cope with additional impacts such as light, vibration and sediment plumes.

Deep Ocean circulation, water masses, bottom currents

Effects of mining unknown, but most probably long lasting and complex in the water column. The low oxygen values of the thermohaline and intermediate waters will likely hinder organic material decomposition, thus increasing sinking rates to the ocean floor. The abyssal domain in the CCZ contains the oldest waters anywhere in the oceans and contains a reservoir of unique and great molecular diversity.

Sedimentation rates and sediment mixing

There is a lack of information on the sensitivity to sediment burial on the scale of the CCZ. There would inevitably be considerable long-term negative biological impact on the majority of the fauna, especially suspension feeders.

Deep seafloor: topography and global geochemical cycles

The ecosystem would be sensitive to topographic modification since the heterogeneity of the substrate and topography play an important role in structuring the faunal assemblages.

Polymetallic nodules: nodule growth and processes maintaining nodules on the seabed

Polymetallic nodule mining cannot be considered as a sustainable activity since the reconstitution of the initial status, even if possible, would take at least 1 million years, based of known rates of nodule growth. Most probably there would be an impact at a regional scale, over an area of more than 3 million $\mathrm{km}^{2}$ of the deep sea floor.

The structure of faunal communities: distribution at different temporal and spatial scales

Highly sensitive. There are a range of biotic and abiotic parameters that determine the structure of the megafaunal communities at both regional and intra-site scales. As mentioned above, biodiversity and abundance of megafauna are enhanced on nodule areas, compared to nodule-free areas. As also mentioned, some taxa evidence highly non-random distributions, making protection a greater challenge.
However, an issue resulting from the mining planned in the CCZ is that even the earliest mining activity will have an environmental impact at a regional scale, both disturbing ecosystems and even covering nodule fields that are the mining target in surrounding areas. Consequently, the recognition of marine protected areas "where sea-floor mining and other deleterious activities are not allowed" is considered impracticable. Instead the International Seabed Authority (ISBA) has referred to "Areas of Particular Environmental Interest (APEI)," and also to "Impact Reference Zones" and "Preservation Reference Zones" (Smith et al., 2008b; Wedding et al., 2017), the purposes of which would be to assist the ISBA in taking decisions concerning the modalities of nodule exploitation and its impact both on the ecosystems concerned and on the future of mining activities.

To serve both as foci for natural recolonization and as valid reference sites, nodule ecosystem conservation areas need to remain effectively unimpacted, to secure which extensive buffer zones, as designated around many large protected areas, are also essential. They should also be fully representative of the areas to be exploited in terms of depth, physical and chemical nature of the substratum, overlying chemistry and oceanography of the water column, and broader climatology, all of which 
ideally require monitoring at different temporal and spatial scales (Freiwald and Roberts, 2006; Académie des Sciences d'Outre-Mer (ASOM), 2010; Tilot, 2010a).

In conformity with the principle of ecosystem-based management and the commitments enshrined in the Convention on Biological Diversity, marine spatial planning in the high seas/deep sea needs to pursue an integrated approach that both considers all stakeholders and sectors of activity and fully appreciates the tri-dimensional status of the oceans (Tilot, 2004; Ardron et al., 2008). The necessary marine spatial planning will require cumulative impact studies that monitor the extent of impact at all scales (Ardron et al., 2008; Foley et al., 2010). In the pelagic domain, numerous species are using the CCZ as feeding grounds near the surface $(0-200 \mathrm{~m}$ for Bluefin tuna according to Block et al., 2002, see map). Some species extend their range to a depth of $1,000 \mathrm{~m}$, such as for yellowfin tuna, bigeye tuna and swordfishes, to $1,500 \mathrm{~m}$ for Bottlenose whale or even approximately 3,000 $\mathrm{m}$ for sperm whale (FAO Fisheries and Aquaculture, 2000; Block et al., 2011; Karleskint et al., 2012; Schor et al., 2014, see maps).

The need must also be emphasized for all international instruments and institutions concerned with the High Seas to coordinate in securing the necessary strategic perspective of marine spatial planning (Ardron et al., 2008; Maes, 2008; Académie des Sciences d'Outre-Mer (ASOM), 2010; Tilot, 2010a). In addition, given the complexity of the system and how little knowledge of its function is available, it is strongly advised that the management system incorporates strong elements of adaptive or reactive management, so that preventative action can be taken so soon as new information becomes available.

\section{Measuring Biodiversity}

It is broadly accepted that a key objective of environmental management is to protect, if not examples of all habitats and ecosystem in a pristine state, then at least as much of a region's biodiversity as is possible. The well-established arguments for preserving both marine and terrestrial species have been well documented and widely accepted and will not be rehearsed here. But, since complex species record matrices such as those summarized here cannot be easily interpreted, it is relevant to consider how best to use them to compare the biodiversity and ecological value of contrasting nodule field habitats, given that a major problem in any study of this type of environment is that only a limited area can be sampled, and that only for conspicuous megafauna.

Historically several indices of species richness, including simple species number, have been used, both to assess the diversity of an area or habitat and to monitor environmental impacts which almost invariably result in a loss of diversity. However a well-known problem with most traditional indices, including a simple count of the number of species present (species richness), is that the values obtained are highly sensitive to the amount of sampling completed (sample size), making comparisons between studies or even different habitats problematic. Some indices such as Simpson's D attempt to compensate for varied sample size, and also to include a measure of the distribution of species between different abundance categories (evenness). Of the widely used diversity indices, we are most inclined to use Fisher's log alpha, since it is generally considered to have good discriminant ability as well as low sample size sensitivity, while being relatively insensitive to the pattern of relative abundances across species (Kempton and Taylor, 1976; Hayek and Buzas, 1997).

However there are two aspects of diversity that traditional diversity indices do not consider: taxonomic diversity-whether the species present are closely or distantly related; and functional diversity-whether the species present perform similar or contrasting functional roles within the ecosystem (Williams et al., 1996; Price, 2002). It has been considered a priority to develop new metrics that are process oriented and that account for ecosystem dynamics across temporal and spatial scales (Steneck, 2001; Price et al., 2007), highlighting so far as possible the importance of key functional groups, ecological roles and species interactions (Hughes et al., 2005). More recently, a number of such indices have been developed that seem relatively intuitive and comprehensive. These include average taxonomic distinctiveness (which is a measure of the mean taxonomic distance between species within a sample or study area), and variation in taxonomic distinctiveness which is a measure of the variance in taxonomic distance between species; both are relatively insensitive to sample size (Warwick and Clarke, 2001). In addition, complementing the idea of taxonomic distinctiveness, the concept of taxonomic similarity, the mean taxonomic distance between species from different samples or sites, has been introduced, allowing comparison across areas at different scales; this measure is likewise relatively insensitive to sampling intensity (Izsak and Price, 2001; Price, 2002; Price and Izsak, 2005). It is increasingly considered that such taxonomic diversity measures of biodiversity at both within-habitat and within-region scales, including across and between large ocean provinces, are invaluable for comparing and monitoring environments where full species lists are impracticable to attain (Warwick and Clarke, 1995, 2001; Gray, 1997; Price, 1999; Izsak and Price, 2001), and we propose their wider use for future assessing and monitoring in the CCZ.

\section{Monitoring and Rapid Environmental Assessment}

Long-term monitoring involving the collect of time-series data has been routinely used in coastal and shallow-water ecosystems, such as coral reefs and mangrove forest, for research and management purposes (http://www.gcrmn.org). A wide variety of different methodologies are used, many incorporating the use of still or video imagery (see for example Tilot, 2003; Tilot et al., 2008a,b). However, as with baseline assessments, a major issue is the limited time and resources that can be allocated to sampling at any one site, to which may be added the extremely large areas over which competent monitoring is often desired. Such issues are especially acute when the need to monitor the benthic environment of the CCZ is considered. Deployment of platforms onto the seabed is extremely expensive, only a tiny fraction of the benthic area can be sampled even during an extended voyage, and only a small proportion of the biota can be detected. In response to similar problems workers in shallow and coastal environments have developed protocols for Rapid 
Environmental (or Ecological) Assessment (REA), typically for use in situations where large areas, hundreds of $\mathrm{km}$ across, need to be assessed, but where no more than a day at most can be spent in sampling at any one site (Price, 1999). In such a situation it is more useful for management purposes to obtain a less precise estimate of abundances across a large sample area, than a very precise estimate over a small sampling area, such as a limited number of quadrats, as is typically attempted in more academic ecological studies.

REAs have in common that they accept semi-quantitative abundance estimates of biological taxa and of environmental factors, often assessed on a pre-defined (often 5- or 6-, or 10point) scale (Van der Maabel, 1979; Lévesque, 1996; Tait and Dipper, 1998), and that in order to assess diversity or monitor the presence of keystone trophic groups they restrict species identification to pre-selected orders or families, for example birds or echinoderms or fish, such as butterflyfish (Hourigan et al., 1988; Roberts et al., 1988; Montevecchi, 1993; Whitfield and Elliott, 2002; Price, 2004). Such systems have been widely developed and used on land by nature conservation agencies, for example in the widely adopted phase $I$ habitat and vegetation classification surveys used by the UK agencies, and have been extended for use in intertidal and subtidal environments, with different habitats and sub-habitats being distinguished on the basis of semi-quantitative but standardized visual estimates of the abundance of key taxa (Nature Conservancy Council, 1990; Rodwell, 1991; Davies et al., 2001). While individual estimates may lack precision, provided methods are applied consistently, statistical methods can be applied to the data, enabling quantitative conclusions to be drawn with equal confidence. Monitoring of deep-sea benthos using the methods described is comparable in that only reasonably conspicuous megafauna can be recorded and that key environmental factors such as sediment type, nodule density and seabed slope, must be assessed visually on a predefined scale. Recording of megafauna via still or video imagery appears to resemble traditional quadrat or transect methodology, but study of such large quantities of imagery can be hugely time-consuming if it is desired to identify every specimen even to genus level, besides which, it must be stressed, many of the megafauna visible in surveys have yet to be identified or even described. Hence there is a strong case for, at least in routine monitoring, subsampling of images, and identification only to order or family level, or trophic or functional group, while restricting determination of species number to a few selected taxa. Where subsequently there is concern about a particular area or taxa, then the archived imagery can be analyzed in full (i.e., without sub-sampling), at a later date, in order to gain greater statistical precision.

In addition, individual taxa may be used as indicator species. For example the Echiurian worm Jacobia birsteini (family Bonellidae) appears to be a strong indicator of specific conditions of current, nodule abundance and size, lithographic sediment features, and trophic conditions favoring the presence of such deposit feeders. By the mounds they build, they generate habitat heterogeneity and also influence the dynamics of epifaunal assemblages; they also have a salient role in sediment irrigation and mixing, and so an action on nodule diagenesis (Tilot,
1995, 2006a,b, 2010b). A second good indicator would be the presence of swimming deep sea holuthurians (Elasipods), such as Enypniastes eximia and Peniagone leander, that seem to be benthopelagical, since they can sometimes be observed at great distance above the seabed (Rogacheva et al., 2012).

Adoption of REA principles does not however exclude the necessity for monitoring of key water column parameters, such as turbidity, current speed, dissolved oxygen concentration, production (chlorophyll), alkalinity etc. It is essential to establish a permanent or semi-permanent tri-dimensional monitoring system recording key environmental variables related to the different mining activities that will take place not only on the seabed, but also in the water column and at the surface. Most of these variables can be measured with sensors, for example current velocity using Lowered Acoustic Doppler Current Profilers (LADCP). Judging by the recent results of Catalá et al. (2015a,b), and the recent research on hydrodynamics close to the seabed (Moreno Navas et al., 2014), and on nepheloid layers (Gardner et al., 1984) in particular for nodule fields (Hoffert, 2008), attention will need to be paid to the selected environmental parameters within five particular depth zones: (i) from the surface to $200 \mathrm{~m}$, (ii) in the central domain $(200-500 \mathrm{~m})$, (iii) within the intermediate domain (500-1,500 $\mathrm{m}$ ), with a pronounced high productivity and pronounced oxygen minimum layer, (iv) in the abyssal domain ( $>1,500-200 \mathrm{~m}$ above the seabed) where are located the oldest water masses of the oceans (between 1,800 and $3,500 \mathrm{~m}$ ), and v) close to the seabed ( $200 \mathrm{~m}$ above to the seabed including the bottom nepheloid layer which may extend $>200 \mathrm{~m}$ above the seabed into the abyssal domain), a most interesting layer with direct implications for the functioning of the nodule ecosystem and its genesis. The data should enable the management body to set up guidelines that can be adapted over time and space to reflect expected impacts (Tilot, 2004, 2010a, 2014).

\section{Ecohydrodynamics and Predictive Modeling}

Generally, the study of ecological communities has been dominated by a single-scale taxonomically narrow approach, which cannot describe the interaction of environmental and stochastic processes across contrasting functional guilds or spatial scales (Weiher et al., 2011). A novel approach to the understanding of deep-sea benthos is the use of mathematical and geospatial tools, such as 3D hydrodynamic models and particle dispersion models, species distribution models, combined with Geographic Information Systems (GIS), to understand how topography, hydrography and species ecology influence the structure of faunal assemblages (Nihoul, 1981; Nihoul and Djenidi, 1991; Harkema and Weatherly, 1996; Moreno Navas et al., 2014). Such ecohydrodynamic modeling can provide a better understanding of the interaction of such variables as food supply, larval transport, community composition, sediment dynamics, and pollutant dispersion, in response to hydrological factors such as currents, internal waves, upwelling, downwelling and bottom topography (Henry et al., 2013). It has been concluded that often lateral and vertical advection of particles plays an important role in the functioning of deep-sea ecosystems. 
Such an approach may also be used to predict the effects of anthropogenic activities. Ecohydrodynamics have for example been applied to a cold-water coral reef ecosystem to predict the effects of bottom fishing and renewable energy installations on reef connectivity and ecosystem function (Watson and Morato, 2004; Henry et al., 2013; Moreno Navas et al., 2014; Roberts and Cairns, 2014). In relation to manganese nodule mining from the deep sea, several studies have modeled sediment transport (Jankowski and Zielke, 2001; GESAMP, 2016), but a broader ecohydrodynamic approach could greatly assist in predicting the nature and scale of the ecological changes likely to be triggered by nodule mining in different sea-floor areas. Similar modeling would also facilitate adoption of a metapopulation persistence approach, since knowledge of dispersal patterns is needed to estimate the patterns of recruitment between different habitat areas and types, so providing key information for marine environmental managers (Botsford and Hastings, 2006).

\section{Use of Management Indices}

The interpretation of even the most intuitive diversity indices represents a challenge to non-specialists. With this in mind, several simpler types of index have been developed for presentation to managers and government. Two increasingly common types are Environmental Sensitivity or Vulnerability Indices, used to indicate the priority that should be accorded to different areas or habitats in protecting them from impact, and Management Alert systems, that are used to assist managers determine when action is required to control developing environmental stress, such as fishing pressure or pollution discharge.

Habitat mapping often based on ground-truthed multispectral imagery imported in to a GIS base map has become one of the most important tools in ecology, finding wide use in resource assessment, environmental impact assessment and biodiversity conservation (e.g., Brown and Collier, 2008; Cogan et al., 2009). Environmental Sensitivity Index (ESI) mapping takes this approach a stage further by, within the GIS, weighting the layers representative of different habitats and communities to indicate both their sensitivity to different classes of impact and the likelihood of those different impacts occurring (Buckley, 1982; Tortell, 1992). Such ESI maps, when complemented by maps of socioeconomic data, can be an invaluable tool for managers in working with stakeholders to identify vulnerable locations, establish protection priorities, and identify strategies for minimizing undesirable environmental consequences and promoting desirable ones. These tools have been widely used in terrestrial environments for many years, although there remains a need to incorporate the value of habitats as surrogates for ecosystem services, because there can be important co-benefits or opportunity costs associated with their conservation and or loss during development (Fraschetti, 2012). ESIs have also been widely applied to the marine environment, where their first application was to risk management of spills in the oil industry (Jensen et al., 1993).

Based on data gathered during the survey of NIXO 45 we assessed the typical (modal) values of each component indicator, and so the values of both Value and Sensitivity Indexes for each facies (Tables $\mathbf{3 A}, \mathbf{B}$ ). The values support the view that overall type $\mathrm{C}$ facies may be considered the most vulnerable, with type $C$ facies $15-20 \%$ on a slope of $>15^{\circ}$ obtaining very similar scores. These facies are significant because, based on the data described here, they host the most diverse and abundant megafauna. After facies $\mathrm{C}$, facies $\mathrm{O}$ with recent sediments have the next highest richness and abundance values. Among other topographic variables, aspect and changes in current speed appear to be important factors the principal factor influencing cold-water coral reef biodiversity, in particular that of suspension feeders, through locally increasing current strength (Henry et al., 2013; Moreno Navas et al., 2014). It is an issue that miners are most interested on facies $\mathrm{C}$ and $\mathrm{B}$ with dense nodule coverage.

\section{Alert Systems}

Alert Systems, in contrast, are still innovative in their application to marine areas, but have for example been proposed in relation to coastal areas and MPAs in the Red Sea, Gulf of Oman and Arabian Gulf (Tilot, 2003, 2016; IUCN/ROWA, 2016). Levels of key biological (e.g., live coral cover) or physical (e.g., sediment load) or chemical (e.g., oil hydrocarbon) parameters are set to trigger management action to halt the damaging activity (such as an oil leak) and implement restitution activities (e.g., oil spill clear up) as previously determined. Often Alert Systems discriminate more than one threshold, often using a traffic lights system (Halliday et al., 2001; Ceriola et al., 2007; Barange et al., 2010), with for example blue indicating pristine, green indicating minimal impact, orange indicating that one or more critical levels of impact are being approached, and red that immediate management intervention is required. There is a need to develop both sensitivity indexes and alert systems for application to the deep sea, particularly in response to the anticipated huge extent of future nodule mining operations. Both maps and alert system should incorporate increasing knowledge of the CCZ nodule ecosystem, so as to inform the implementation of strict environmental guidelines and secure the desirable conservation-based management responses. The effectiveness of both sensitivity maps and alert systems will be greatly enhanced if ecohydrodymanic models can be incorporated in them, enabling managers to visualize more directly the way in which short- or long-term changes in hydrodynamic environment will impact the biota.

\section{AUTHOR CONTRIBUTIONS}

VT discusses the results of a unique comprehensive study she performed on imagery taken on 5 sites of the CCFZ and proposes options for conservation and management using a marine spatial planning approach on the basis of her experience in other marine domains. She proposes with the team to apply these tools to one of the sites she studied. RO worked with VT on the interpretation of the results and the development of $3 \mathrm{D}$ environmental assessments, vulnerability indexes and other tools adapted from experience in shallower waters in the world. JMN worked on the GIS and Ecohydrodynamics modeling adapted to the selected study sites on the basis of his experience in cold-water coral communities and coastal zone management. TC 
contributed with the analysis of water mass samples of the CCZ taken during the Malaspina circumnavigation expedition in 2010. Her results were fed into the discussions, in particular for the $3 \mathrm{D}$ monitoring of the water column.

\section{FUNDING}

We received notice by Frontiers that we were allocated a waiver to cover full cost of submission.

\section{ACKNOWLEDGMENTS}

The research presented in this paper would not have been possible without the support of the "Institut Français de Recherche pour l'Exploitation de la Mer" (IFREMER), which made available its facilities, cruises, data, and expertise, through teams from the departments of Deep Ocean Ecosystems and Marine Geosciences, with the funding from the European Commission, DG Enterprise and Industry and the "Institut Océanographique de Paris" (France). Cruises and data were also been made available by SCRIPPS (Dr. George Wilson) for the ECHO I site and by the University of Hamburg, (Prof H. Thiel), for the DISCOL cruise in the Peru Basin, South Pacific. Later support was provided by the "Intergovernmental Oceanographic Commission of UNESCO (IOC-UNESCO) and the Government of Flanders to update and expand the work with data from IOM on the BIE site. This would not have been possible without the collaboration of Dr. Kotlinski (Director IOM),

\section{REFERENCES}

Aller, R. (1997). Benthic community response to temporal and spatial gradients in physical disturbance within a deep-sea western boundary region. Deep Sea Res. I 44, 39-69. doi: 10.1016/S0967-0637(96)00092-1

Amon, D. J., Ziegler, A. F., Dahlgren, T. G, Glover, A. G, Goineau, A., Gooday, A. J., et al. (2016). Insights into the abundance and diversity of abyssal megafauna in a polymetallic-nodule región in the Eastern Clarion-Clipperton Zone. Nat. Sci. Rep. 6:30492. doi: 10.1038/srep30492

Amos, A. F., Mos, A. F., Roels, O. A., Garside, C., and Malone, T. C. (1977). "Environmental aspects of nodule mining," in Marine Manganese Deposits, ed G. P. Glasby (Amsterdam: Elsevier Publication Company), 391-437.

Ardron, J., Gjerde, K., Pullen, S., and Tilot, V. (2008). Marine spatial planning in the high seas. Mar. Policy 32, 832-839. doi: 10.1016/j.marpol.2008.03.018

Académie des Sciences d'Outre-Mer (ASOM) (2010). "Recommendations on the conservation and management of biodiversity of three deep-sea ecosystems targeted by mining (polymetallic nodules, cobalt rich ferro-manganese crusts and hydrothermal sulfurs)," in Proceedings of the International Workshop organized at Unesco, 15 December.

Baldwin, R. J., Glatts, R. C., and Smith, K. L. (1998). Particulate matter fluxes into the benthic boundary layer at a long time-series station in the abyssal NE Pacific: composition and fluxes. Deep Sea Res. II 45, 643-665. doi: 10.1016/S0967-0645(97)00097-0

Barange, M., Field, J. G., Harris, R. P., Hofmann, E. H., Perry, R. I., and Werner, F. E. (eds.). (2010). Marine Ecosystems and Global Change. Oxford; New York, NY: Oxford University Press. doi: 10.1093/acprof:oso/9780199558025.001.0001

Barnett, T. P., Adam, J. C., and Lettenmaier, D. P. (2005). Potential impacts of a warming climate on water availability in snow-dominated regions. Nature 438, 303-309. doi: 10.1038/nature04141

Beaulieu, S. E., and Smith, K. L. Jr. (1998). Phytodetritus entering the benthic boundary layer and aggregated on the sea floor in the abyssal NE Pacific: Macro- and microscopic composition. Deep Sea Res. II 45, 781-815. doi: 10.1016/S0967-0645(98)00003-4
Dr. Stoyanova and Dr. Radziejewska. Data for the water mass analysis was available thanks to the Malaspina expedition (grant number CSD2008-00077). The authors also thank the National Museum of Natural History, Paris (France), the "Instituto Español de Oceanografía," Malaga (Spain), the Centre for Marine Biodiversity and Biotechnology of Heriot-Watt University (UK), the Physical Oceanography Research Group of the Universidad de Málaga, Spain and the CSIC Instituto de Investigacións Mariñas (Spain), Departamento de Ecología and Instituto del Agua, Universidad de Granada (Spain). We are also grateful to Prof. A. Vanreusel, Dr. Arthur Dahl (UNEP), Dr. Kenneth Sherman (NOAA), Dr. Andrew Hudson (UNDP), Dr. Alain Jeudy de Grissac, and Dr. Michael Pearson. We also thank Prof. Michel Hoffert, Jean-Pierre Lenoble, Dr. Gilles Ollier (EU), Dr. Yves Fouquet, Philippe Saget, and Anne Sophie Alix (IFREMER) for sharing their knowledge of the deep-sea mineral resources, and also Elie Jarmache, Special Advisor on the Law of the Sea, Secretariat General of the Sea of France. We are especially grateful to the $>150$ specialists who assisted in the identification, so far as was practicable, of the taxa referred to; they are listed in Appendix III of volume 1 of the IOC/UNESCO report (Tilot, 2006a) which is reproduced as supplementary material document 1 .

\section{SUPPLEMENTARY MATERIAL}

The Supplementary Material for this article can be found online at: https://www.frontiersin.org/articles/10.3389/fmars. 2018.00007/full\#supplementary-material

Behrenfeld, M. J., O’Malley, R. T., Siegel, D. A., McClain, C. R., Sarmiento, J. L., Feldman, G. C., et al. (2006). Climate-driven trends in contemporary ocean productivity. Nature 444, 752-755. doi: 10.1038/nature 05317

Berkes, F., Colding, J. C., and Folke, C. (2003). Navigating Socio-Ecological Systems: Building Resilience for Complexity and Change, Ecology and Society. Cambridge: Cambridge University Press.

Billett, D. S. M., Llewellyn, C., and Watson, J. (1988). “Are deep-sea holothurians selective feeders?" in Echinoderm Biology: Proceedings of the 6th International Echinoderm Conference Victoria, eds R. D. Burke, P. V. Mladenov, P. Lambert, and R. L. Parsley (Rotterdam: Balkema), 255-266.

Block, B. A., Costa, D. P., Boehlert, G. W., and Kochevar, R. E. (2002). Revealing pelagic habitat use: the tagging of Pacific pelagics program. Oceanol. Acta 25, 255-266. doi: 10.1016/S0399-1784(02)01212-4

Block, B. A., Jonsen, I. D., Jonsen, S. J., Winship, A. J., Schaefer, S. A., Bograd, S. J., et al. (2011). Tracking apex marine predator movements in a dynamic ocean. Nature 475, 86-90. doi: 10.1038/nature10082

Bluhm, H. (1997). "Megafauna as indicators for the recolonization of abyssal areas impacted by physical disturbances," in International Symposium on Environmental Studies for Deep-Sea Mining (Tokyo), 49-63.

Bluhm, H. (2001). Re-establishment of an abyssal megabenthic community after experimental physical disturbance of the seafloor. Deep Sea Res. II 48, 3841-3868. doi: 10.1016/S0967-0645(01)00070-4

Bluhm, H., Schriever, G., and Thiel, H. (1995). Megabenthic recolonization in an experimentally disturbed abyssal manganese nodule area. Mar. Georesources Geotechnol. 13, 393-416.

Botsford, L. W., and Hastings, A. (2006). "Conservation dynamics of marine metapopulations with dispersing larvae," in Marine Metapopulations, eds J. P. Kritzer and P. F. Sale (Amsterdam: Academic Press), Ch. 12, 411-429, 544.

Brown, C. J., and Collier, J. S. (2008). Mapping benthic habitat in regions of gradational substrata: an automated approach utilising geophysical, geological, and biological relationships. Estuar. Coast. Shelf Sci. 78, 203-214. doi: 10.1016/j.ecss.2007.11.026 
Buckley, R. C. (1982). Environmental sensitivity mapping - what, why and how. Miner. Environ. 4, 151-155. doi: 10.1007/BF02085976

Catalá, T. S., Reche, I., Fuentes-Lema, A., Romera-Castillo, C., Nieto-Cid, M., Ortega-Retuerta, E., et al. (2015a). Turnover time of fluorescent dissolved organic matter in the dark global ocean. Nat. Commun. 6:5986. doi: $10.1038 /$ ncomms6986

Catalá, T. S., Reche, I., Álvarez, M., Khatiwala, S., Guallart, E. F., Benítez-Barrios, V. M., et al. (2015b). Water mass age and ageing driving chromophoric dissolved organic matter in the dark global ocean. Global Biogeochem. Cycles 29, 1-18. doi: 10.1002/2014GB005048

Ceriola, L., Ungaro, N., and Toteda, F. (2007). A "Traffic Light" approach for the assessment of the Broadtail shortfin squid Illex coindetii Verany, 1839 in the Southern Adriatic Sea (Central Mediterranean). Rev. Fish Biol. Fish. 17:145. doi: 10.1007/s11160-006-9019-5

Chung, J. S., Schriever, G., Sharma, R., and Yamazaki, T. (2001). "Deep seabed mining environment: engineering and environment assessment," in Proceedings of ISOPE-Ocean Mining Symposium (Szczecin), 8-14.

Cogan, C. B., Todd, B. J., Lawton, P., and Noji, T. T. (2009). The role of marine habitat mapping in ecosystem-based management. ICES J. Mar. Sci. 66, 2033-2042. doi: 10.1093/icesjms/fsp214

Corrigan, C., and Kershaw, F. (2008). Working Toward High Seas Marine Protected Areas: An Assessment of Progress Made and Recommendations for Collaboration. Cambridge: UNEP/WCMC.

Cury, P., and Shannon, L. (2004). Regime shifts in upwelling ecosystems: observed changes and possible mechanisms in the northern and southern Benguela. Prog. Oceanogr. 60, 223-243. doi: 10.1016/j.pocean.2004.02.007

Danovaro, R. (2008). Exponential decline of deep-sea ecosystem functioning linked to benthic biodiversity loss. Curr. Biol. 18, 1-8. doi: 10.1016/j.cub.2007.11.056

Davies, J., Baxter, J., Bradley, M., Connor, D., Khan, J., Murray, E., et al. (2001). Marine Monitoring Handbook. Peterborough: Joint Nature Conservation Council.

Dayton, P. K., and Hessler, R. R. (1972). Role of biological disturbance in maintaining diversity in the deep-sea. Deep Sea Res. 19, 199-208. doi: 10.1016/0011-7471(72)90031-9

Dittmar, T. (2015). "Reasons behind the long-term stability of dissolved organic matter," in Biogeochemistry of Marine Dissolved Organic Matter, 2nd Edn., eds A. D. Hansell and C. A. Carlson (London: Elsevier Academic Press), 369-388.

Drazen, J. C., Baldwin, R. J., and Smith, K. L., Jr. (1998). Sediment community response to a temporally varying food supply at an abyssal station in the NE Pacific. Deep Sea Res. II 45, 893-913. doi: 10.1016/S0967-0645(98)00007-1

Du Castel, V. (1985). Etablissement d’une Carte Géologique au 1/20.000e d'un Domaine Océanique Profond Dans une Zone Riche en Nodules Polymétalliques du Pacifique Nord (zone Clarion-Clipperton). Ph.D. dissertation thesis, Université de Bretagne Occidentale, Brest, 259.

Dugolinsky, B. K., Margolis, S. V., and Dudley, W. C. (1977). Biogenic influence on growth of manganese nodules. J. Sediment. Petrol 47:428e445.

Dymond, J., and Collier, R. (1988). Biogenic particle fluxes in the equatorial Pacific: evidence for both high and low productivity during the 1982-1983 El Niño. Glob. Biogeochem. Cycles 2, 129-137.

Edgar, G. J., Russ, G. R., and Babcock, R. C. (2007). "Marine protected areas," in Marine Ecology, eds S. D. Connell and B. M. Gillanders (Oxford: Oxford University Press), 533-555.

ESCO CNRS IFREMER (2014). Impacts environnementaux de l'exploitation des ressources minerales marines profondes. Rapport D'expertise Scientifique Collective. 939

FAO Fisheries and Aquaculture (2000). Biological Characteristics of Tuna. Michel Goujon and Jacek Majkowski. Available online at: http://www.fao.org/fishery/ topic/16082/en

Feely, R., Sabine, C., Lee, K., Berelson, W., Kleypas, J., Fabry, V., et al. (2004). Impact of Anthropogenic $\mathrm{CO} 2$ on the $\mathrm{CaCO} 3$ system in the oceans. Science 305, 362-366. doi: 10.1126/science.1097329

Fiedler, P. C., and Talley, L. D. (2006). Hydrography of the eastern tropical Pacific: a review. Prog. Oceanogr. 69, 143-180. doi: 10.1016/j.pocean.2006.03.008

Flood, R. D. (1983). Classification of sedimentary furrows and a model for furrows initiation and evolution. Geol. Soc. Am. Bull. 94, 630-639. doi: 10.1130/0016-7606(1983)94<630:COSFAA > 2.0.CO;2

Foell, E., Thiel, H., and Schriever, G. (1990). "DISCOL: a long-term large scale disturbance-recolonisation experiment in the abyssal Eastern Tropical Pacific
Ocean," in Proceedings of Offshore Technology Conference (Houston, TX), 497-503.

Foley, M. M., Halpern, B. S., Micheli, F., Armsby, M. H., Caldwell, M. R., Crain, C. M., et al. (2010). Guiding ecological principles for marine spatial planning. Mar. Policy 34, 955-966. doi: 10.1016/j.marpol.2010.02.001

Folke, C., Carpenter, S., Walker, B., and Scheffer, M. (2004). Regime shifts, resilience and biodiversity in ecosystem management. Ann. Rev. Ecol. Evol. Syst. 35, 557-581. doi: 10.1146/annurev.ecolsys.35.021103.105711

Fraschetti, S. (2012). Mapping the marine environment: advances, relevance and limitations in ecological research and in marine conservation and management. Biol. Mar. Mediterr. 19, 79-83.

Friedrich, G., and Plüger, W. (1974). The distribution of manganese, iron, cobalt, nickel, copper and zinc in manganese nodules in various fields. Meerestechnik 6, 203-206.

Freiwald, A., and Roberts, J. M. (2006). "Cold-water corals and ecosystems," in Erlangen Earth Conference Series, eds A. Freiwald and J. M. Roberts (Berlin; Heidelberg: Springer-Verlag), 1243.

Fukushima, T. (1995). "Japan deep-sea impact experiment=JET," in Proceedings of ISOPE Ocean Mining Symposium (Tsukuba), 47-53.

Fukushima, T., Shirayama, Y., and Kuboki, E. (2000). The characteristics of deep-sea epifaunal megabenthos community two years after an artificial rapid deposition event. Publ. Seto Mar. Lab. 39, 17-27.

Gage, J. D., and Tyler, P. A. (1991). Deep-sea Biology: A Natural History of Organisms at the Deep-Sea Floor. Cambridge: Cambridge University Press. doi: $10.1017 /$ СBO9781139163637

Galeron, J., Scolan, P., Fifis, A., and Sibuet, M. (2006). "Spatial variability of megafaunal assemblages in deep-sea polymetallic nodule fields in the North-East Pacific. Oral presentation," in 11th Deep-Sea BiologySymposium (Southampton).

Game, E. T., Grantham, H. S., Hobday, A. J., Pressey, R. L., Lombard, A. T., Beckley, L., et al. (2009). Pelagic protected areas: the missing dimension in ocean conservation. Trends Ecol. Evol. 24, 360-369. doi: 10.1016/j.tree.2009.01.011

Gardner, W. D., and Sullivan, L. G. (1981). Benthic storms: temporal variability in a deep-ocean nepheloid layer. Science 213:3. doi: 10.1126/science.213.4505.329

Gardner, W. D., Sullivan, L. G., and Thorndike, E. M. (1984). Longterm photographic, current, and nephelometer observations of manganese nodule environments in the Pacific. Earth Planet. Sci. Lett. 70, 95-109. doi: 10.1016/0012-821X(84)90212-7

GESAMP (2016). Proceedings of the GESAMP International Workshop on the Impacts of Mine Tailings in the Marine Environment. (IMO/FAO/UNESCOIOC/UNIDO/WMO/IAEA/UN/UNEP/UNDP Joint Group of Experts on the Scientific Aspects of Marine Environmental Protection). Rep. Stud. GESAMP 94:84.

Ghosh, A. K., and Mukhopadhyay, R. (2000). Mineral Wealth of the Ocean. Rotterdam: A.A. Balkema.

Gianni, M., Fuller, S. D., Currie, D. E. J., Schleit, K., Goldsworthy, L., Pike, B., et al. (2016). How Much Longer Will It Take? A Ten-Year Review of the Implementation of United Nations General Assembly Resolutions 61/105, 64/72 and 66/68 on the Management of Bottom Fisheries in Areas beyond National Jurisdiction. Amsterdam: Deep Sea Conservation Coalition. Available online at: http://www.savethehighseas.org/publicdocs/DSCC-Review-2016_Launch29-July.pdf

Glover, A. G., and Smith, C. R. (2003). The deep-sea floor ecosystem: current status and prospects of anthropogenic change by the year 2025. Environ. Conserv. 30, 219-241. doi: 10.1017/S0376892903000225

Glover, A. G., Smith, C. R., Paterson, G. I. J., Wilson, G. D. F., Hawkins, L., and Sheader, M. (2002). Polychaete species diversity in the central Pacific abys: local and regional patterns and elationships with productivity. Mar. Ecol. Prog. Ser. 2002, 157-170. doi: 10.3354/meps240157

Glover, A. G., Gooday, A. J., Bailey, D. M., Billett, D. S. M., Chevaldonné, P., Colaço, A., et al. (2010). Temporal change in deep-sea benthic ecosystems: a review of the evidence from recent time-series studies. Mar. Biol. 58, 1-95. doi: 10.1016/B978-0-12-381015-1.00001-0

Gollner, S., Kaiser, S., Menzel, L., Jones, D. O. B., Brown, A., Mestre, N. C., et al. (2017). Resilience of benthic deep-sea fauna to mining activities. Mar. Environ. Res. 129, 76-101. doi: 10.1016/j.marenvres.2017.04.010

Gooday, A. J. (2002). Biological responses to seasonally varying fluxes of organic matter to the ocean floor: a review. J. Oceanogr. 58, 305-332. doi: 10.1023/A:1015865826379 
Gooday, A. J., Goineau, A., and Voltski, I. (2015). Abyssal foraminifera attached to polymetallic nodules from the eastern Clarion Clipperton Fracture Zone: a preliminary description and comparison with North Atlantic dropstone assemblages. Mar. Biodivers. 45:391e412. doi: 10.1007/s12526-0140301-9

Grassle, J. F., and Sanders, H. L. (1973). Life histories and the role of disturbance. Deep Sea Res. 20, 643-659.

Gray, J. S. (1977). The stability of benthic ecosystems. Helgoländer Wissenschaftliche Meeresuntersuchungen 30, 427-444. doi: 10.1007/BF02207852

Gray, J. S. (1997). Marine biodiversity: patterns, threats and conservation needs. Biodivers. Conserv. 6, 153-175. doi: 10.1023/A:1018335901847

Gundersen, L. H., and Pritchard, L. (eds.). (2002). Resilience and the Behaviour of Large-Scale Systems. Washington, DC: Island Press.

Haedrich, R. L., and Rowe, G. T. (1977). Megafaunal biomass in the deep-sea. Nature 269, 141-142. doi: 10.1038/269121a0

Halbach, P., Friedrich, G., and von Stackelberg, U. (1988). The Manganese Nodule Belt of the Pacific Ocean: Geological Environment, Nodule Formation, and Mining Aspects Stuttgart: Enke Verlag.

Halliday, R. G., Fanning, L. P., and Mohn, R. K. (2001). Use of traffic light method in fishery management planning. Canadian Science Advisory Secretariat, Res. Doc. No 2001/108, 41. Available online at: http://www.dfo-mpo.gc.ca/csas/ Csas/DocREC/2001/RES2001_108e.pdf

Hannides, A. K., and Smith, C. R. (2003). "The northeastern Pacific abyssal plain," in Biogeochemistry of Marine Systems, Chapter 10, eds K. D. Black and G. B. Shimmield (Oxford: Blackwell Science), 208-237.

Harada, K., and Nishida, S. (1979). Biochronology of Some Pacific Manganese Nodules and their Growth Mechanism. Gif-sur-Yvette: Colloques Internationaux du CNRS.

Harkema, R., and Weatherly, G. L. (1996). A compilation of moored currentmeter data from the southern boundary of the Brazil basin for the deep basin experiment September 1993-March 1995. Tech. Rep. CMF 9601.

Hartmann, M. (1979). Evidence for early diagenetic mobilization of trace metals from dislocation of pelagic sediments. Chem. Geol. 26, 277-293. doi: 10.1016/0009-2541(79)90051-2

Hayek, L.-A. C., and Buzas, M. A. (1997). Surveying Natural Populations. New York, NY: Columbia University Press.

Heezen, B., and Hollister, C. (1971). The Face of the Deep. New York, NY: Oxford University Press.

Henry, L.-A., Moreno Navas, J., and Roberts, J. M. (2013). Multi-scale interactions between local hydrography, seabed topography, and community assembly on cold-water coral reefs. Biogeosciences 10, 2737-2746. doi: 10.5194/bg-10-2737-2013

Heye, D. (1988). The internal microstructure of manganese nodules and their relationship to the growth rate. Mar. Geol. 26, 59-66. doi: 10.1016/0025-3227(78)90058-0

Hoffert, M. (2008). Les Nodules Polymétalliques Dans Les grands Fonds Océaniques, une Extraordinaire Aventure Minière et Scientifique Sous-Marine, Editions VUIBERT. Paris: Société géologique de France, 430.

Hoffert, M., and Saget, P. (2004). Manuel D' identification des "Facies-Nodules" Pour la Zone de Plongées NIXO45. Rapport Interne IFREMER, Plouzané.

Hollister, C. D., and McCave, I. N. (1984). Sedimentation under deep-sea storms. Nature 309, 220-225. doi: 10.1038/309220a0

Hollister, C. D., and Nowell, A. R. M. (1991). HEBBLE epilogue. Mar. Geol. 99, 445-460. doi: 10.1016/0025-3227(91)90055-9

Hourigan, T. F., Timothy, C. T., and Reese, E. S. (1988). "Coral reef fishes as indicators of environmental stress in coral reefs," in Marine Organisms as Indicators, eds D. F. Soule and G. S. Kleppel (New York, NY: Springer), 107-135.

Hughes, T. P., Baird, A. H., Bellwood, D. R., Card, M., Connolly, S. R., Folke, C., et al. (2003). Climate change, human impacts and the resilience of coral reefs. Science 301, 929-933. doi: 10.1126/science.1085046

Hughes, T. P., Bellwood, D. R., Folke, C., Steneck, R., and Wilson, J. (2005). New paradigms for supporting the resilience of marine ecosystems. Trends Ecol. Evol. 20, 380-385. doi: 10.1016/j.tree.2005.03.022

Huisman, J., Thi, N. N. P., Karl, D. M., and Sommeijer, B. (2006). Reduced mixing generates oscillations and chaos in the oceanic deep chlorophyll maximum. Nature 439, 322-325. doi: 10.1038/nature04245
INTERNATIONAL SEA BED AUTHORITY (ISBA) (2008). “Technical study no. 3: Biodiversity, species ranges, and gene flow in the abyssal Pacific nodule province: predicting and managing the impacts of deep seabed mining," in International Seabed Authority of the "Kaplan Project", eds C. R. Smith, J. Galeron, A. Gooday, A. Glover, H. Kitazato, L. Menot, et al. 45.

IUCN/ROWA (2016). Ecological Baseline Assessment using Environmental Sensitivity Index Mapping for Al Daymaniyat Islands, Oman Sultanate. IUCN/ROWA Report, 170.

Izsak, C., and Price, A. R. G. (2001). Measuring s-diversity using a taxonomic similarity index, and its relation to spatial scale. Mar. Ecol. Progr. Ser. 215, 69-77. doi: $10.3354 /$ meps 215069

Jankowski, J., and Zielke, W. (2001). The mesoscale sediment transport due to technical activities in the deep sea. Deep Sea Res. II 48, 3487-3521. doi: 10.1016/S0967-0645(01)00054-6

Janssen, A., Kaiser, S., Meißner, K., Brenke, N., Menot, L., Martínez Arbizu, P. (2015). A reverse taxonomic approach to assess macrofaunal distribution patterns in abyssal pacific polymetallic Nodule fields. PLoS ONE 10:e0117790. doi: 10.1371/journal.pone. 0117790

Jensen, J. R., Narumalani, S., Weatherbee, O., Murday, M., Sexton, W. J., and Green, C. (1993). Coastal environmental sensitivity mapping for oil spills in the United Arab Emirates using remote sensing and GIS technlogy. Geocarto Int. 8, 5-13. doi: 10.1080/10106049309354404

Jones, D. O., Kaiser, S., Sweetman, A. K., Smith, C. R., Menot, L., Vink, A. et al. (2017). Biological responses to disturbance from simulated deep-sea polymetallic nodule mining. PLoS ONE 12:e0171750. doi: 10.1371/journal.pone.0171750

Jumars, P. A., Mayer, L. M., Deming, J. W., Baross, J. A., and Wheatcroft, R. A. (1990). Deep-sea deposit feeding strategies suggested by environmental and feeding constraints. Philos. Trans. R. Soc. Lond. A 331, 85-101.

Karl, D. (2002). Nutrient dynamics in the deep blue sea. Trends Microbiol. 10, 410-418. doi: 10.1016/S0966-842X(02)02430-7

Karl, D. M., Christian, J. R., Dore, J. E., Hebel, D. V., Letelier, R. M., Tupas, L. M., et al. (1996). Seasonal and interannual variability in primary production and particle flux at Station ALOHA. Deep Sea Res. II 43, 539-568.

Karleskint, G., Turner, R., and Small, J. (2012). Introduction to Marine Biology, 4th Edn., Boston, MA: Brooks Cole.

Kempton, R. A., Taylor, L. R. (1976). Models and statistics for species diversity. Nature 262, 818-820.

Kennett, J. P. (1982). Marine Geology. Englewood Cliffs, NJ: Prentice Hall Inc.

Kessler, W. (2006). The circulation of the eastern tropical Pacific: a review. Progr. Oceanogr. 69, 181-217. doi: 10.1016/j.pocean.2006.03.009

Klein, H. (1987). Benthic storms, vortices and particle dispersion in the Deep West European Basin. Dtsch. Hydrol. Z. 49, 87-102.

Kontar, E. A., and Sokov, A. V. (1994). A benthic storm in the northeastern tropical Pacific over the fields of manganese nodules. Deep Sea Res. 41, 1069-1089.

Kontar, E. A., and Sokov, A. V. (1997). On the benthic boundary layer's dynamics. J. Mar. Syst. 11, 369-385.

Kotlinski, R. (1998). The present state of knowledge on oceanic polymetallic ores as exemplified by Interoceanmetal Joint Organization's activity. Miner. Polonica $29,77-89$.

Kotlinski, R. (1999). Metallogenesis of the world's ocean against the background of oceanic crust evolution. Pol. Geol. Inst. Spec. Papers 4, 1-59.

Kritzer, J. P., and Sale, P. F. (eds.). (2010). Marine Metapopulations. Amsterdam: Academic Press, 544.

Lauerman, L. M., Smoak, J. M., Shaw, T. J., Moore, W. S., and Smith, K. L. (1997). $234 \mathrm{Th}$ and $210 \mathrm{~Pb}$ evidence from rapid ingestion of settling particles by mobile epibenthic megafauna in the abyssal NE Pacific. Limnol. Oceanogr. 42, 589-595.

Lévesque, E. (1996). Minimum area and cover-abundance scales as applied to polar desert vegetation. Arctic Alpine Res. 156-162.

Levin, L. A., Demaster, D. J., McCann, L. D., and Thomas, C. L. (1986). Effects of giant protozoans (class Xenophyophorea) on deep-seamount benthos. Mar. Ecol. Prog. Ser. 29, 99-104.

Levin, L. A., Etter, R. J., Rex, M. A., Gooday, A. J., Smith, C. R., Pineda, J., et al. (2001). Environmental influences on regional deep-sea species diversity. Annu. Rev. Ecol. Systemat. 32, 51-93.

Levitus, S., Antonov, J. I., Boyer, T. P., and Stephens, C. (2000). Warming of the world ocean. Science 287, 2225-2229. doi: 10.1126/science.287.5461.2225 
Longhurst, A. R. (2007). Ecological Geography of the Sea, 2nd Edn. Burlington: Burlington Academic Press.

Loreau, M. (2008). Biodiversity and ecosystem functioning: the mystery of the deep sea. Curr Biol. 18, R126-R128.

Maes, F. (2008). The international legal framework for marine spatial planning. Mar. Policy. 32, 797-810. doi: 10.1016/j.marpol.2008.03.013

Margules, C. R., and Pressey, R. L. (2000). Systematic conservation planning. Nature 405, 243-253.

Mauviel, A., and Sibuet, M. (1985). "Répartition des traces animales and importance de la bioturbation," in Peuplements profonds du Golfe de Gascogne. Campagne Biogas, eds L. Laubier and C. Monniot (Brest: Ifremer), 157-173.

McCartney, M. S. (1982). The subtropical recirculation of mode waters. J. Mar. Res. $40,427-464$.

McGowan, J. A., Cayan, D. R., and Dorman, L. M. (1998). Climate-ocean variability and ecosystem response in the northeast Pacific. Science 281, 210-217.

McMurtry, G. (2001). "Authigenic deposits," in Encyclopedia of Ocean Sciences, eds S. A. Thorpe and K. K. Turekian (London: Academic Press), 201-220.

Menard, H. W. (1964). Geology of the Pacific Ocean. New York, NY: McGraw-Hill Inc.

Menzies, R. J., George, R., and Rowe, G. T. (1973). Abyssal Environment and Ecology of the World Oceans. New York, NY: John Wiley and Sons.

Montevecchi, W. A. (1993). "Birds as indicators of change in marine prey stocks," in Birds as Monitors of Environmental Change, eds R. W. Furness and J. J. D. Greenwood (London: Chapman and Hall), 217-266.

Morgan, C. (1991). Geographical Distributions of Benthic Megafauna in the ClarionClipperton Zone. NOAA Report.

Morgan, C. L. (2000). "Resource estimates of the Clarion-Clipperton manganese nodule deposits," in Handbook of Marine Mineral Deposits, ed D. S. Cronan (Boca Raton, FL: CRC Press), 145-170.

Moreno Navas, J., Miller, P. I., Henry, L. A., Hennige, S. J. and Roberts, J. M. (2014). Ecohydrodynamics of cold-water coral reefs: a case study of the Mingulay Reef Complex (Western Scotland). PLoS ONE 9:e98218. doi: 10.1371 /journal.pone.0098218

Mullineaux, L. S. (1987). Organisms living on manganese nodules and crusts: distribution and abundance at three North Pacific sites. Deep Sea Res. 34, $165-184$.

Muschenheim, D. K. (1987). The dynamics of near-bed seston flux and suspensionfeeding benthos. J. Mar. Res. 45, 473-496.

Nature Conservancy Council (1990). Handbook for Phase 1 Habitat Survey - A Technique for Environmental Audit. England Field Unit. Peterborough: Nature Conservancy Council.

Nihoul, J. C. J. (1981). "Marine hydrodynamics at ecological scales," in Ecohydrodynamics, ed J. C. J. Nihoul (Amsterdam: Elsevier Press), 1-12.

Nihoul, J. C. J., and Djenidi, S. (1991). Hierarchy and scales in marine ecohydrodynamics. Earth Sci. Rev. 31, 255-277.

Nowell, A. R. M., Hollister, C. D., and Jumars, P. A. (1982), High energy benthic boundary layer experiment: HEBBLE. Eos Trans. AGU 63, 594-595.

Oebius, H. U., Becker, H. J., Rolinski, S., and Jankowski, J. (2001). Parametrization and evaluation of marine environmental impacts produced by deep-sea manganese nodule mining. Deep Sea Res. II 48, 3453-3467. doi: 10.1016/S0967-0645(01)00052-2

O’Leary, B. C., Brown, R. L., Johnson, D. E., Von Nordheim, H., Ardron, J., Packeiser, T., et al. (2012). The first network of marine protected areas (MPAs) in the high seas: the process, the challenges and where next. Mar. Policy 36, 598-605. doi: 10.1016/j.marpol.2011.11.003

Ozturgut, E., Lavelle, J. W., Steffin, O., Swift, S. A. (1980), Environmental Investigation during Manganese Nodule Mining Tests in the North Equatorial Pacific, in November 1978. NOAA Tech. Memorandum ERL MESA-48, NOAA, 50.

Paterson, G. L. J., Menot, L., Colaço, A., Glover, A. G., Gollner, S., Kaiser, S., et al. (2015). Biogeography and connectivity in deep-sea habitats with mineral resource potential gap analysis. MIDAS Deliv. 4:45. Available online at: http:// www.vliz.be/imisdocs/publications/41/268441.pdf

Peterson, G., Allen, C. R., and Holling, C. S. (1998). Ecological resilience, biodiversity, and scale. Ecosystems 1:6e18.

Petersen, S., Kratschell, A., Augustin, N., Jamieson, J., Hein, J. R., and Hannington, M. D. (2016). News from the seabed: Geological characteristics and resource potential of deep-sea mineral resources. Mar. Policy 70, 175-187. doi: 10.1016/j.marpol.2016.03.012

Pennington, T. J., Mahoney, K. L., Kuwahara, V. S., Kolber, D. D., Calienes, R., and Chavez, F. P. (2006). Primary production in the eastern tropical Pacific: a review. Prog. Oceanogr. 69, 285-317. doi: 10.1016/j.pocean.2006.03.012

Pfannkuche, O., and Lochte, K. (1993). Open ocean pelago-benthic coupling: cyanobacteria as tracers of sedimenting salp feces. Deep Sea Res I. 40, 727-737.

Price, A. R. G. (1999). "Broadscale coastal environmental assessment of the Chagos Archipelago," in Sheppard CRC, Seaward MRD, eds Ecology of the Chagos Archipelago (London: Westbury Publishing/Linnean Society Occasional Papers), 285-296.

Price, A. R. G. (2002). Simultaneous 'hotspots' and 'coldspots' of marine biodiversity and implications for global conservation. Mar. Ecol. Progr. Ser. 241, 23-27. doi: $10.3354 / \mathrm{meps} 241023$

Price, A. R. G. (2004). "Rapid coastal environmental assessment," in Standard Survey Methods for the Red Sea and Gulf of Aden (PERSGA/GEF). PERSGA Technical Series 10. PERSGA, Jeddah, 1-2.

Price, A. R. G., and Izsak, C. (2005). Is the Arabian Gulf really such a lowspot of biodiversity?: scaling effects and management implications. Aquat. Ecosyst. Health Man. 8, 363-366. doi: 10.1080/14634980500457757

Price, A. R. G., Jobbins, G., Shepard, A. R. D., and Ormond, R. F. G. (1998). An integrated environmental assessment of the Red Sea coast of Saudi Arabia. Environ. Conserv. 25, 65-76.

Price, A. R. D., Keeling, M., and Stewart, I. (2007). A robustness metric integrating spatial and temporal information: application to coral reefs exposed to local and regional disturbances. Mar. Ecol. Prog. Ser. 331, 101-108.

Quirchmayr, R. (2015). On the existence of benthic storms. J. Nonlin. Math. Phys. 22, 540-544.

Radziejewska, T. (1997). "Immediate responses of benthic meio- and megafauna to disturbance caused by polymetallic nodule miner simulator," in Proceedings of the International Symposium on Environmental Studies for Deep-Sea Mining (Tokyo), 223-235.

Radziejewska, T. (2002). Responses of deep-sea meiobenthic communities to sediment disturbance simulating effects of polymetallic nodule mining. Int. Rev. Hydrobiol. 87, 457-477. doi: 10.1002/1522-2632(200207)87:4<457::AID-IROH457>3.0.CO;2-3

Radziejewska, T., and Stoyanova, V. (2000). Abyssal epibenthic megafauna of the Clarion-Clipperton area (NE Pacific): changes in time and space versus anthropogenic environmental disturbance. Oceanol. Stud. 29, 83-101.

Ramirez-Llodra, E., Tyler, P. A., Baker, M. C., Bergstad, O. A., Clark, M. R., Escobar, E., et al. (2011). Man and the last great wilderness: human impact on the deep sea. PLoS ONE 6:e22588. doi: 10.1371/journal.pone.0022588

Rex, M. A. (1983). "Geographic patterns of species diversity in the deep-sea benthos," in Deep Sea Biology, ed G. T. Rowe (New York, NY: John Wiley \& Sons), 453-472.

Rex, M., and Etter, R. (2010). Deep-Sea Biodiversity; Pattern and Scale. Harvard, MA: Harvard University Press.

Richardson, M. J., Weatherly, G. L., and Gardner, W. D. (1993). Benthic storms in the Argentine Basin. Deep Sea Res. II 40, 975-987.

Roberts, M., and Cairns, S. (2014). Cold-water corals in a changing ocean. Curr. Opin. Environ. Sustain. 7, 118-126. doi: 10.1016/j.cosust.2014.01.004

Roberts, C. M., Ormond, R. F. G., and Shepherd, A. D. (1988). "The usefulness of butterflyfishes as environmental indicators on coral reefs," in Proceedings of the 6th Interntional Coral Reef Symposium: Vol. 2: Contributed Papers, eds J. H. Choat, D. Barnes, M. A. Borowitzka, J. C. Coll, P. J. Davies, P. Flood, B. G. Hatcher, D. Hopley, P. A. Hutchings, D. Kinsey, G. R. Orme, M. Pichon, P. F. Sale, P. Sammarco, C. C. Wallace, C. Wilkinson, E. Wolanski and O. Bellwood (Townsville, QLD), 331-336.

Roberts, C. M., Bohnsack, J. A., Gell, F., Hawkins, J. P., and Goodridge, R. (2001). Effects of marine reserves on adjacent fisheries. Science 294, 1920-1923. doi: 10.1126/science.294.5548.1920

Rodwell, J. S. (ed.). (1991). British Plant Communities, Vol. 1. Woodlands and Scrub. Cambridge: Cambridge University Press.

Rogacheva, A., Gebruk, A., and Alt, C. (2012). Swimming deep-sea holothurians (Echinodermata: Holothuroidea) on the northern Mid-Atlantic Ridge. Zoosymposia 7, 213-224. doi: 10.11646/zoosymposia.7.1.19

Rolinski, S., Segschneider, J., and Sündermann, J. (2001). Long-term propagation of tailings from deep-sea mining under variable conditions by means of numerical simulations. Deep Sea Res. II 48, 3469-3485. 
Rowe, G. T. (1971). "Benthic biomass and surface productivity," in Fertility of the Sea, ed J. D. Costlow (New York, NY: Gordon and Breach), 97-122.

Ruhl, H. A., and Smith, K. L. Jr. (2004). Shifts in deep-sea community structure linked to climate and food supply. Science 305, 513-515. doi: 10.1126/science.1099759

Sarmiento, J. L., Slater, R., Barber, R., Bopp, L., Doney, S. C., Hirst, A. C., et al. (2004). Response of ocean ecosystems to climate warming. Glob. Biogeochem. Cycles. 18:GB3003. doi: 10.1029/2003GB002134

Schneider, J. (1981). Manganese nodules in the deep sea. Formation, ocurrence and ecological consequences of mining. Natur Museum III, 114-124.

Schneider, D. C., Gagnon, J. M., and Gilkinson, K. D. (1987). Patchiness of epibenthic megafauna on the outer Grand Banks of Newfoundland. Mar. Ecol. Prog. Ser. 39, 1-13.

Schor, G. S., Falcone, E. A., Moretti, D. J., and Andrews, R. D. (2014). First long-term behavioral Records from Cuvier's beaked whales (Ziphius cavirostris) reveal record-breaking dives. PLoS ONE 9:e92633. doi: 10.1371/journal.pone. 0092633

Schriever, G., Ahnert, A., Borowski, C., Thiel, H. (1997). "Results of the large scale deep-sea impact study DISCOL during 8 years of investigation," in Proceedings of the International Symposium on Environmental Studies for Deep-Sea Mining, Metal Mining Agency of Japan (Tokyo), 237-243.

Sharma, R. (2015). Environmental Issues of Deep-Sea Mining. Global Challenges, Policy Framework and sustainable development for mining of mineral and fossil energy resources (GCPF2015). Proc. Earth Planet. Sci. 11, 204-211. doi: 10.1016/j.proeps.2015.06.026

Sharma, R., and Rao, A. (1992). Geological factors associated with megabenthic activity in the Central Indian Basin. Deep Sea Res. 39, 705-713.

Sharma, R., Nagender Nath, B., Parthiban, S., and Jai Sankar, S. (2001). Sediment redistribution during simulated benthic disturbance and its implications on deep seabed mining. Deep Sea Res. II 48, 3363-3380.

Shirayama, Y. (1999). "Biological results of JET Project: an overview," in Proceedings of ISOPE Ocean Mining Symposium (Goa), 185-190.

Shor, G. (1959). Reflexion studies in the eastern equatorial Pacific. Deep Sea Res. 5, 283-285.

Sibuet, M. (1987). Structure des Peuplements Benthiques en Relation Avec Les Conditions Trophiques en Milieu Abyssal dans l'Océan Atlantique. Thèse de Doctorat d'Etat ès Sciences Naturelles, Université P. et M. Curie (Paris), 1-280.

Smith, C. R. (1999). "The biological environment in the nodule provinces of the deep sea," in Deep-Seabed Polymetallic Nodule Exploration: Development of Environmental Guidelines, ed N. Odunton (Kingston: International Seabed Authority), 41-68.

Smith, C. R., and Rabouille, C. (2002). What controls the mixed-layer depth in deep-sea sediments? The importance of POC flux. Limnol. Oceanogr. 49, 620-622. doi: 10.4319/lo.2004.49.2.0620

Smith, C. R., and Baco, A. R. (2003). Ecology of whale falls at the deep-sea floor. Oceanogr. Mar. Biol. Annu. Rev. 41, 311-354.

Smith, C. R., and Demopoulos, A. (2003). "Ecology of the deep. Pacific Ocean floor," in Ecosystems of the World, 28: Ecosystems of the Deep. Ocean, ed P. A. Tyler (Amsterdam: Elsevier), 179-218.

Smith, C. R., Jumars, P. A., and DeMaster, D. J. (1986). In situ studies of megafaunal mounds indicate rapid sediment turnover and community response at the deep-sea floor. Nature 323, 251- 252.

Smith, C. R., Berelson, W., Demaster, D. J., Dobbs, F. C., Hammond, D., Hoover, D. J., et al. (1997). Latitudinal variations in benthic processes in the abyssal equatorial Pacific: control by biogenic particle flux. Deep Sea Res. II 44, 2295-2317.

Smith, C. R., Levin, L., Koslow, A., Tyler, P., and Glover, A. (2008a). “The near future of the deep sea floor ecosystems," in Aquatic Ecosystems: Trends and Global Prospects, ed N. Polunin (Cambridge: Cambridge University Press), 334-349.

Smith, C., Gaines, S., Watling, L., Friedlander, A., Morgan, C., Thurnherr, A., et al. (2008b). Rationale and Recommendations for the Establishment of Preservation Reference Areas for Nodule Mining in the Clarion-Clipperton Zone. Fourteenth session. Kingston, 26 May-6 June 2008, sessions/2008/documents: Legal and Technical Commission, International Seabed Authority.Technical document no. ISBA/14/LTC/2. Available online at: https://www.isa.org.jm/ (click/contractors/exploration-areas/Clarion Clipperton Fracture Zone)

Smith, K. L., and Kaufmann, R. S. (1999). Long-term discrepancy between food supply and demand in the deep eastern north Pacific. Science 284, 1174-1177.
Smith, K. L. J. R., Kaufmann, R. S., and Wakefield, W. (1993). "Mobile megafaunal activity monitored with a time-lapse camera in the abyssal North Pacific," in Deep Sea Research Part I: Oceaonographic Research Papers, 40 11-12, November-December 1993, 2307-2324.

Smith, K. L., Kaufmann, R. S., Baldwin, R. J., and Carlucci, A. F. (2001). Pelagic-benthic coupling in the abyssal eastern North Pacific: an 8-year timeseries study of food supply and demand. Limnol. Oceanogr. 46, 543-556. doi: 10.4319/lo.2001.46.3.0543

Smith, K. L., Ruhl, H., Bett, B., Billett, D., Lampitt, R., and Kaufmann, R. (2009). Climate, carbon cycling and dep-ocean ecosystems. Proc. Natl. Acad. Sci. U.S.A. 106, 19211-19218. doi: 10.1073/pnas.0908322106

Snelgrove, P. V. R., and Smith, C. R. (2002). "A riot of species in an environmental calm: the paradox of the species-rich deep sea," in Oceanography and Marine Biology: An Annual Review, eds R. N. Gibson, M. Barnes, and R. J. A. Atkinson (London: CRC Press), 311-342.

Spiess, F. N., Hessler, R., Wilson, G., and Weydert, M. (1987). Environmental effects of deep sea dredging. NOAA Rep. 87, 1-85.

Steneck, R. S. (2001). "Functional groups," in Encyclopedia of Biodiversity, Vol. 3, ed S. A. Levin (San Diego, CA: Academic Press), 121-139.

Stoyanova, V. (2008). "Some peculiarities of distribution patterns of polymetallic nodules associated megabenthic community," in Interoceanmetal Joint Organization. Oral Communication at the Panel Discussion "A Proposition of Strategy of Conservation for a Nodule Ecosystem in the Clarion-Clipperton Fracture Zone, NE Pacific Ocean." UNESCO/IOC (Accessed 12 December, 2008).

Tait, R. V., and Dipper, F. A. (1998). Elements of Marine Ecology, 4th Edn. Oxford: Butterworth Heinemann.

Talley, L. D., Pickard, G., Emery, W., and Swift, J. (2011). Descriptive Physical Oceanography: An Introduction, 6 th Edn. Boston, MA: Elsevier Academic Press.

Thiel, H. (2003). "Anthropogenic impacts on the deep-sea," in Ecosystems of the World: The Deep Sea, ed P. A. Tyler (Amsterdam: Elsevier).

Thiel, H., Foell, E., and Schriever, G. (1991). "Megafauna observations and experiments with a time lapse camera," in Proceedings of 6th Deep-Sea Biology Symposium (Copenhagen).

Thiel, H., Schriever, G., Bussau, C., and Borowski, C. (1993). Managanese nodule crevice fauna. Deep Sea Res. 40, 419-423. doi: 10.1016/0967-0637(93)90012-R

Thiel, H., Schriever, G., Ahnert, A., Bluhm, H., Borowski, C., and Vopel, K. (2001). The large scale environmental impact experiment DISCOL - reflection and foresight. Deep Sea Res. II 48, 3869-3882. doi: 10.1016/S0967-0645(01)00071-6

Thurston, M. H., Rice, A. L., and Bett, B. J. (1998). Latitudinal variation in invertebrate megafaunal abundance and biomass in the North Atlantic Ocean abyss. Deep Sea Res. II 45, 203-224.

Tilot, V. (1988). Review of Environmental Impact studies on Deep-Sea Polymetallic Mining in the Eastern Central Pacific Ocean. Contract CEE CDC/88/7730/IN/01: 1-59. Report for the Commission of the European Communities Directorate-General for Science, Research and Development.

Tilot, V. (1989). Report to EU of the German Oceanographic on - a DIS-Turbance and re-COL-Onization Experiment DISCOL II in the Peru Basin, South Pacific. Contract CEE CDC/88/7730/IN/01: 1-59. Report for the Commission of the European Communities Directorate-General for Science, Research and Development.

Tilot, V. (1990). "The review of megafauna in the NIXONAUT cruise," in Film Presented at Law of the Sea Treaty Meeting (Montego Bay).

Tilot, V. (1991). Report on the Description of Megafaunal Assemblages and Manganese Nodule Coverage Along Transects Taken during the Benthic Impact Experiment (NOAA-BIE) cruise by NOAA and SCRIPPS, USA. June 24-July 1991. Contract CEE CDC/90/7730/IN/01: 1-59. Report for the Commission of the European Communities Directorate-General for Science, Research and Development.

Tilot, V. (1992). La Structure des Assemblages Mégabenthiques d’une Province à Nodules Polymétalliques de l'Océan Pacifique tropical Est. Ph.D. dissertation thesis, University of Bretagne Occidentale, Brest.

Tilot, V. (1995). An ecologically important type of biological activity in a deepsea ferro-manganese nodule environment of the tropical north east Pacific. Mesogée 54, 101-120.

Tilot, V. (2003). Final Report on the Gulf of Aqaba Monitoring Programme (GAMP). Egyptian Environmental Agency Affairs (EEAA) and European Commission, National Parks of Egypt Protectorates Development Programmes project. SEM 04/220/027 A. 
Tilot, V. (2004). Management Plan for the Marine Mammals Sanctuary in the Mediterranean Sea. Pelagos. Adopted by the Governments of France, Italy and Monaco in October 2004, Signatories to the Agreement on the Creation of a Sanctuary for Marine Mammals, 107 (accessed 25 November, 1999).

Tilot, V. (2006a). Biodiversity and Distribution of the Megafauna Vol 1 The Polymetallic Nodule Ecosystem of the Eastern Equatorial Pacific Ocean. Intergovernmental Oceanographic Commission. Technical Series 69, Project Unesco COI/Min, Vlanderen. Available online at: http://unesdoc.unesco.org/ images/0014/001495/149556f.pdf

Tilot, V. (2006b). Biodiversity and Distribution of the Megafauna Vol 2 Annotated Photographic Atlas of the Echinoderms of the Clarion-Clipperton Fracture Zone. Intergovernmental Oceanographic Commission. Technical Series 69, Project Unesco/COI/Min Vlanderen. Available online at: http://unesdoc.unesco.org/ images/0014/001495/149556f.pdf

Tilot, V. (2006c). "Megabenthic assemblages of polymetallic nodule ecosystems in the Clarion-Clipperton Fracture Zone within the abyssal tropical East Pacific," in Proceedings of Workshop on Prospects for International Collaboration in Marine Environmental Research to Enhance Understanding of the Deep-Sea Environment, International Seabed Authority (Kingston), 1-14.

Tilot, V. (2010a). Biodiversity and Distribution of Faunal Assemblages Vol 3 Options for the Management and Conservation of the Nodule Ecosystem in the Clarion Clipperton Fracture Zone (NE Pacific Ocean): Scientific, Legal and Institutional Aspects. Technical Series 69, Project Unesco COI/Min Vlanderen. Available online at: http://unesdoc.unesco.org/images/0014/001495/149556e.pdf\#223

Tilot, V. (2010b). "Panorama of epibenthic megafaunal communities in a deep sea nodule ecosystem of the CCZ, NE Pacific Ocean," in UNESCO/IOC, Tech. Series 69, Vol. 3. Availabel online at: http://unesdoc.unesco.org/images/0014/001495/ 149556e.pdf\#223

Tilot, V. (2011). "Recommendations for the conservation and management of the biodiversity of deep sea ecosystems targeted by seabed mining (Polymetallic Nodule Deposits, Cobalt-Rich Ferromanganese Crusts and Hydrothermal Sulfides)," in Proceedings 40th Annual Conference of the Underwater Mining Institute (Hilo, HI).

Tilot, V. (2013). “Tools for marine spatial management in deep seas (A guide for Research, Conservation and Development Practitioners)," in Proceedings of the International Marine Protected Areas Congress (IMPAC3), IUCN/Agence des Aires Marines Protégées (Fr) (Marseille).

Tilot, V. (2014). “An innovative Multilayer Rapid Ecological Assessment adapted to monitoring and management of Deep Sea Ecosystems," in Proceedings Deep Sea Mining Summit 2014 (London).

Tilot, V. (2016). General Features of the Coral Reef Communities of the Daymaniyat Islands, Oman Sultanate and Designation of Management Indexes for Environmental Sensitivity Mapping. IUCN/ROWA Report.

Tilot, V., Leujak,W., and Ormond, R. (2008a). Monitoring of south sinai coral reefs: influence of natural and anthropogenic factors. Aquat. Conserv. Mar. Freshw. Ecosyst. 18, 1109-1126. doi: 10.1002/aqc.942

Tilot, V., Veron, J., and Jeudy de Grissac, A. (2008b). “The coral reefs of eritrea: little known gems," in Status of the Coral Reefs of the World, Vol. 78, ed C. Wilkinson (Townsville: Global Coral Reef Monitoring Network/International Coral Reef Initiative), 296.

Tkatchenko, G., and Radziejewska, T. (1998). "Recovery and recolonization processes in the area disturbed by a polymetallic nodule collector simulator," in Proceedings of the 8th ISOPE Conference, vol. 2, eds J. S. Chung, M. Olagnon, C. H. Kim, and W. Koterayama (Montreal, QC), 282-286.

Tkatchenko, G., Radziejewska, T., Stoyanova, V., Modlitba, I., and Parizek, A. (1996). "Benthic impact experiment in the IOM pioneer area: testing for effects of deep-sea disturbance," in Int. Sem. On Deep Sea Mining, Metal Mining Agency of Japan (Tokyo), 223-236.

Tortell, P. (1992). Coastal zone sensitivity mapping and its role in marine environmental management. Mar. Poluti. Bull. 25, 88-93.

Trueblood, D. D., Ozturgut, E., Philipchuk, M., and Gloumov, I. F. (1997). "The ecological impacts of the Joint US-Russian Benthic Impact Experiment," in Proceedings of International Symposium on Environmental Studies for Deep-Sea Mining, Metal Mining Agency of Japan (Tokyo), 237-243.

Tsuchiya, M. (1981). The origin of the Pacific Equatorial $13^{\circ} \mathrm{C}$ water. J. Phys. Oceanogr. 11, 794-812.
Tundi Agardy, M. (1994). Advances in marine conservation: the role of marine protected areas. Trends Ecol. Evol. 9, 267-270. doi: 10.1016/0169-5347(94)90297-6

Tyler, P. A. (1988). Seasonality in the deep sea. Oceanogr. Mar. Biol. Annu. Rev. 26, 227-258.

Tyler, P. A. (2003). Ecosystems of the World. 28. Ecosystems of the Deep Oceans. Amsterdam: Elsevier Press.

Van der Maabel, E. (1979). Transformation of cover-abundance values in phytosociology and its effects on community similarity. Vegetation 39, 97-114.

Vanreusel, A., Hilario, A., Ribiero, P., Menot, L., and Martinez Arbizu, P. (2016). Threatened by mining polymetallic nodules are required to preserve abyssal epifauna. Sci. Rep. 6:26808. doi: 10.1038/srep26808

Veillette, J., Juniper, S. K., Gooday, A. J., and Sarrazin, J. (2007a). Influence of surface texture and microhabitat heterogeneity in structuring nodule faunal communities. Deep Sea Res. I Oceanogr. Res. Pap. 54, 1936-1943. doi: 10.1016/j.dsr.2007.06.012

Veillette, J., Sarrazin, J., Gooday, A. J., Galeron, J., Caprais, J. C., Vangriesheim, A., et al. (2007b). Ferromanganese nodule fauna in the Tropical North Pacific Ocean: species richness, faunal cover and spatial distribution. Deep Sea Res. I Oceanogr. Res. Pap. 54, 1912-1935. doi: 10.1016/j.dsr.2007.06.011

Voisset, M., and Hein, P. (1978). Géochimie des Nodules du Pacifique Nord-Est. Rapports Scientifiques et Techniques du CNEXO. Ifremer.

von Stackelberg, U., and Beiersdorf, H. (1991). The formation of manganese nodules between the Clarion and Clipperton fracture zones southeast of Hawaii. Mar. Geol. 98, 411-423.

Wakefield, W., and Genin, A. (1987). The use of a canadian (perspective) grid in deep-sea photography, Deep Sea Res. 34, 469-478.

Wang, C. S., Liao, L., Xu, H. X., Xu, X. W., Xu, M., and Zhu, L. Z. (2010). Bacterial diversity in the sediment from polymetallic Nodule fields of the Clarion-Clipperton fracture Zone. J. Microbiol. 48, 573-585. doi: 10.1007/s12275-010-0151-5

Wang, Y., Li, J., Han, X., and, W. Z. (2001). The influence of terrain slope on the distribution of polymetallic nodules. Acta Oceanol. Sin. 23, 65-23.

Warwick, R. M., and Clarke, K. R. (1995). New ‘biodiversity’ index measures reveal a decrease in taxonomic distinctness with increasing stress. Mar. Ecol. Progr. Ser. 129, 301-305.

Warwick, R. M., and Clarke, K. R. (2001). Practical measures of marine biodiversity based on relatedness of species. Oceanogr. Mar. Biol. Annu. Rev. 39, 207-231.

Watson, R., and Morato, T. (2004). "Exploitation patterns in seamount fisheries: a preliminary analysis," in Seamounts: Biodiversity and Fisheries, Fisheries Centre Research Report, Vol. 12, eds T. Morato and D. Pauly (Vancouver: University of British Columbia), 61-66.

Wedding, L. M., Friedlander, A. M., Kittinger, J. N., Watling, L., Gaines, S. D., Bennett, M., et al. (2017). From principles to practice: a spatial approach to systematic conservation planning in the deep sea. Proc. Roy. Soc. B 280:20131684. doi: 10.1098/rspb.2013.1684

Weiher, E., Freund, D., Bunton, T., Stefanski, A., Lee, T., and Bentivenga, S. (2011). Advances, challenges and a developing synthesis of ecological community assembly theory. Philos. Trans. R. Soc. B 366, 2403-2413. doi: $10.1098 /$ rstb.2011.0056

Williams, P., Gibbons, D., Margules, C., Rebelo, A., Humphries, C., and Pressey, R. (1996). A comparison of richness hotspots, rarity hotspots and complementary areas for conserving diversity of British birds. Conserv. Biol. 10, 155-174.

Whitfield, A. K., and Elliott, M. (2002). Fishes as indicators of environmental and ecological changes within estuaries: a review of progress and some suggestions for the future. J. Fish Biol. 61, 229-250. doi: 10.1111/j.1095-8649.2002.tb01773.x

Conflict of Interest Statement: The authors declare that the research was conducted in the absence of any commercial or financial relationships that could be construed as a potential conflict of interest.

Copyright (C) 2018 Tilot, Ormond, Moreno Navas and Catalá. This is an open-access article distributed under the terms of the Creative Commons Attribution License (CC $B Y)$. The use, distribution or reproduction in other forums is permitted, provided the original author(s) and the copyright owner are credited and that the original publication in this journal is cited, in accordance with accepted academic practice. No use, distribution or reproduction is permitted which does not comply with these terms. 